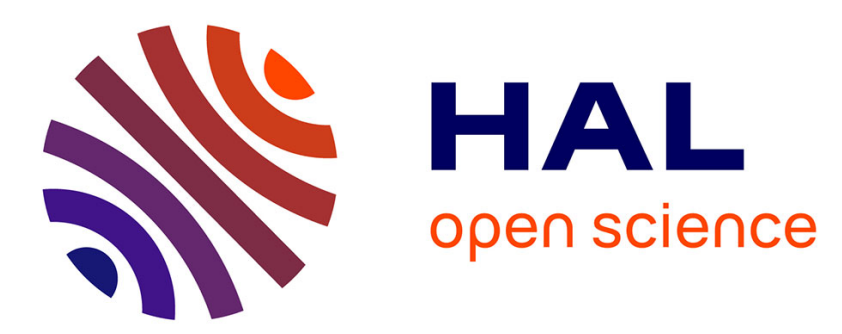

\title{
Effect of electrochemically-driven technologies on the treatment of endocrine disruptors in synthetic and real urban wastewater
}

Alexsandro J dos Santos, Ana S Fajardo, Matheus S Kronka, Sergi GarciaSegura, Marcos R V Lanza

\section{To cite this version:}

Alexsandro J dos Santos, Ana S Fajardo, Matheus S Kronka, Sergi Garcia- Segura, Marcos $\mathrm{R} \mathrm{V}$ Lanza. Effect of electrochemically-driven technologies on the treatment of endocrine disruptors in synthetic and real urban wastewater. Electrochimica Acta, 2021, 376, pp.138034. 10.1016/j.electacta.2021.138034 . hal-03367229v2

HAL Id: hal-03367229

https://hal.sorbonne-universite.fr/hal-03367229v2

Submitted on 7 Oct 2021

HAL is a multi-disciplinary open access archive for the deposit and dissemination of scientific research documents, whether they are published or not. The documents may come from teaching and research institutions in France or abroad, or from public or private research centers.
L'archive ouverte pluridisciplinaire HAL, est destinée au dépôt et à la diffusion de documents scientifiques de niveau recherche, publiés ou non, émanant des établissements d'enseignement et de recherche français ou étrangers, des laboratoires publics ou privés. 


\section{Effect of electrochemically-driven technologies on the treatment of endocrine disruptors in synthetic and real urban wastewater}

Alexsandro J. dos Santos ${ }^{\mathrm{a}, *}$, Ana S. Fajardo ${ }^{\mathrm{b}, \mathrm{c},}, * *$, Matheus S. Kronka ${ }^{\mathrm{a}}$, Sergi GarciaSegura $^{\mathrm{b}}$ and Marcos R. V. Lanza ${ }^{\mathrm{a}, * * *}$

${ }^{a}$ São Carlos Institute of Chemistry, University of São Paulo, Avenida Trabalhador SanCarlense 400, São Carlos, SP 13566-590, Brazil

${ }^{b}$ Nanosystems Engineering Research Center for Nanotechnology-Enabled Water Treatment, School of Sustainable Engineering and the Built Environment, Arizona State University, Tempe, AZ 85287-3005, USA

'Sorbonne Université, CNRS, Laboratoire Interfaces et Systèmes Electrochimiques (LISE), 4 place Jussieu, F-75005, Paris, France

*Corresponding authors' e-mails:

alexsandrojhones@usp.br (A.J. dos Santos)

adossan3@asu.edu (A.S. Fajardo)

marcoslanza@usp.br (M.R.V. Lanza) 


\begin{abstract}
While it remains a challenging task, having a fundamental understanding of the influence of water matrix composition is of central importance for the removal of pollutants in electrochemical treatment processes. This work studied the effect of the complexity of different water matrices on the removal of endocrine disruptors using different electrochemical advanced oxidation processes (EAOPs) based on $\mathrm{H}_{2} \mathrm{O}_{2}$ electrogeneration. The study helped improve the understanding of synthetic and real urban wastewater, and the effective mechanisms for the treatment of pollutants in these effluents. The results obtained showed that, regardless of the medium applied, there was an increase in pollutants mineralization in the following order, based on the EAOPs method employed: electrochemical oxidation with $\mathrm{H}_{2} \mathrm{O}_{2}$ electrogeneration $\left(\mathrm{EO}-\mathrm{H}_{2} \mathrm{O}_{2}\right)<$ electro-Fenton $(\mathrm{EF})<$ photoelectro-Fenton (PEF). Despite the slower degradation kinetics of the $\mathrm{EO}-\mathrm{H}_{2} \mathrm{O}_{2}$ process, its wider $\mathrm{pH}$ range makes it suitable for implementation. Aside the degradation/mineralization performance of the $\mathrm{EO}-\mathrm{H}_{2} \mathrm{O}_{2}$ process, a time-course analysis was conducted on the nitrogen and chloride-based ions in the solution investigated since their presence is vital for determining the final use of the treated effluents based on the parameters of water quality. These parameters include the established maximum concentration levels of the compounds in the water matrix allowed for human consumption or the legal limits of discharge for wastewater treatment facilities. The findings help shed light on the role of coexisting species in water matrix, since this affects the efficiency and competitiveness of EAOPs. Clearly, having detailed knowledge of the water matrix composition will help one to have a better understanding of EAOPs, and this will enable to obtain higher degradation levels in water treatment processes.
\end{abstract}


Keywords: Bisphenol A; methyl paraben; paracetamol; inorganic species; real wastewater; water matrix

\section{Introduction}

Currently, water scarcity and pollution are among the major challenges faced by humanity. This situation has been dramatically intensified by the increase in world population and the incessant quest for the improvement of life quality [1]. In fact, some of the so-called "new helpful daily life products", as is the case of plastic bottles and containers, linings of metal food cans, detergents, flame retardants, food, toys, drugs and cosmetics, and pesticides, have been shown to have adverse effects on both the environment and humans over time [27]. The natural and man-made chemicals that are used in manufacturing these products end up being disposed of into the environment spreading across the ecosystem; these chemicals contain endocrine disruptors, which have been found to be extremely hazardous to humans and the ecosystem as a whole [8]. The endocrine disruptors may mimic or interfere with the body's hormones causing developmental, reproductive, brain, and immune-related problems. Many studies published in the literature have reported the presence of endocrine disruptors in wastewater disposed of into the environment and in water bodies $[9,10]$. Conventional water treatment processes have been demonstrated to be inefficient when it comes to the degradation of these recalcitrant organic pollutants $[11,12]$. Electrochemical advanced oxidation processes (EAOPs) have emerged as a sustainable alternative for the removal of endocrine disruptors where the electron is used as green reagent for the in-situ generation of oxidants [13]. The degradation of organic pollutants by EAOPs occurs via strong reactive oxygen species such as hydroxyl radical $\left({ }^{\bullet} \mathrm{OH}\right)$; this radical is a non-selective oxidant with a high standard reduction potential of $\mathrm{E}^{\circ}=2.80 \mathrm{~V}$ vs SHE. In the case of the electrochemical oxidation (EO) process, ${ }^{\bullet} \mathrm{OH}$ radical is obtained from water electrolysis occurring on the 
surface of the anode (Eq. 1) [14-16]. The ${ }^{\bullet} \mathrm{OH}$ electrogenerated during anodic oxidation remains adsorbed on the electrode surface and the degradation of organic compounds is limited by mass transfer.

$$
\mathrm{M}+\mathrm{H}_{2} \mathrm{O} \rightarrow \mathrm{M}\left({ }^{\bullet} \mathrm{OH}\right)+\mathrm{H}^{+}+\mathrm{e}^{-}
$$

One will note, however, that other indirect electrochemical processes can promote the formation of ${ }^{\bullet} \mathrm{OH}$ in the bulk. This is the case of electrochemical processes based on Fenton reaction (2). The electro-Fenton (EF) process relies on the use of carbonaceous cathodes to promote the selective bi-electronic reduction of oxygen to hydrogen peroxide $\left(\mathrm{E}^{0}=0.695 \mathrm{~V}\right.$ vs $\mathrm{SHE}$ ) via reaction (2) [17]. Electrogenerated $\mathrm{H}_{2} \mathrm{O}_{2}$ can then react with $\mathrm{Fe}^{2+}$ in the solution to yield ${ }^{\bullet} \mathrm{OH}$ through reaction (3) [18]. The EF system not only allows the continuous dosing of $\mathrm{H}_{2} \mathrm{O}_{2}$ without the need of transport, storage, and handling but also enables the fast regeneration of the $\mathrm{Fe}^{2+}$ catalyst from the electrochemical reduction of $\mathrm{Fe}^{3+}$ through reaction (4) $[19-21]$.

$$
\begin{aligned}
& \mathrm{O}_{2(\mathrm{~g})}+2 \mathrm{H}^{+}+2 \mathrm{e}^{-} \rightarrow \mathrm{H}_{2} \mathrm{O}_{2} \\
& \mathrm{H}_{2} \mathrm{O}_{2}+\mathrm{Fe}^{2+} \rightarrow \mathrm{Fe}^{3+}+{ }^{\bullet} \mathrm{OH}+\mathrm{OH}^{-} \\
& \mathrm{Fe}^{3+}+\mathrm{e}^{-} \rightarrow \mathrm{Fe}^{2+}
\end{aligned}
$$

The degradation performance of the EF process can be markedly enhanced when the treated solution is subjected to simultaneous irradiation with UV light through the photoelectro-Fenton (PEF) process. The light conveyed into the solution promotes photondriven reactions, such as the regeneration of iron catalyst based on reaction (5), and mineralization of iron-carboxylate complexes through charge transfer reactions from the ligand to the metal based on the general reaction (6) [22,23]. 


$$
\begin{aligned}
& \mathrm{Fe}(\mathrm{OH})^{2+}+\mathrm{h} v \rightarrow \mathrm{Fe}^{2+}+\bullet \mathrm{OH} \\
& \mathrm{Fe}(\mathrm{OOCR})+\mathrm{h} v \rightarrow \mathrm{Fe}^{2+}+\mathrm{CO}_{2}+\mathrm{R}^{\bullet}
\end{aligned}
$$

Despite the promising results obtained from the degradation of organic persistent pollutants, there are a few questions that remain unanswered regarding the competitiveness of electrochemically-driven Fenton processes. Previous studies have shown the high competitiveness of electrochemical treatment processes during the treatment of ultrapure water containing only one target pollutant. However, the treatment of endocrine disruptors can be affected by the coexistence of different species in real water matrices. To the best of our knowledge, this problem has neither been thoroughly explored nor has it been widely established in the literature [24]. This work aims to investigate the effect of the complexity of the constituents of natural water matrices on the removal of endocrine disruptors. To this end, the present study sought to evaluate the efficiency of EAOPs in the treatment of synthetic and real urban wastewater contaminated with endocrine disruptors with the aim of investigating the effect of the water matrix. The study also quantified the accumulated amount of $\mathrm{H}_{2} \mathrm{O}_{2}$, pollutant degradation rates, total organic carbon (TOC) removal, and the amount of carboxylic acids generated. Engineering figures of merit were used to evaluate the operational requirements for electrical energy per order $(\mathrm{EE} / \mathrm{O})$ and the efficient use of electron delivered in terms of Faradaic efficiency. The understanding of these key aspects can help pave the way toward the large-scale industrial application of this technology for commercialization purposes. 


\section{Experimental}

\subsection{Reagents}

The endocrine disruptors used for the experiments included bisphenol A (BPA, Sigma Aldrich), methyl paraben (MetP, Supelco), and paracetamol (PAC, Sigma Aldrich) with > $99 \%$ purity. Analytical grade sodium sulfate $\left(\mathrm{Na}_{2} \mathrm{SO}_{4}\right)$ and iron (II) sulfate heptahydrate $\left(\mathrm{FeSO}_{4} \cdot 7 \mathrm{H}_{2} \mathrm{O}\right)$, acquired from Sigma-Aldrich, were used in the experiments. Carboxylic acids with $>99 \%$ purity, acquired from Sigma-Aldrich, were used as analytical standards (i.e., acetic, formic, malic and oxalic acids). The ionic species present in the water matrices were quantified by ion chromatography using standard solutions prepared from inorganic salts containing $\mathrm{K}^{+}, \mathrm{Mg}^{2+}, \mathrm{Ca}^{2+}, \mathrm{NH}_{4}{ }^{+}, \mathrm{NO}_{2}{ }^{-}, \mathrm{NO}_{3}{ }^{-}, \mathrm{Cl}^{-}, \mathrm{ClO}_{3}{ }^{-}, \mathrm{ClO}_{4}{ }^{-}$and $\mathrm{SO}_{4}{ }^{2-}$ (acquired from Specsol). All solutions were prepared using ultrapure water from a Millipore Milli-Q system with resistivity $>18.2 \mathrm{M} \Omega \mathrm{cm}$ at $25^{\circ} \mathrm{C}$.

\subsection{Aqueous matrices}

The electrochemical treatments were performed in five different water matrices numbered (i)-(v) aiming at evaluating the effect of the specific components in the water matrices. First, the endocrine disruptors were treated under conventional conditions using ultrapure water containing $\mathrm{Na}_{2} \mathrm{SO}_{4}$ as single supporting electrolyte. These experiments were conducted in (i) $50 \mathrm{mmol} \mathrm{L}^{-1} \mathrm{Na}_{2} \mathrm{SO}_{4}$ solutions prepared in Milli-Q water with conductivity of $7.20 \mathrm{mS} \mathrm{cm}^{-1}$. Second, similar conditions were employed using $\mathrm{NaCl}$ as alternative single supporting electrolyte - this is representative of one of the most evaluated electrolytes in the literature. Solutions of (ii) $50 \mathrm{mmol} \mathrm{L}^{-1} \mathrm{NaCl}$ were prepared in Milli-Q water with conductivity of $6.50 \mathrm{mS} \mathrm{cm}{ }^{-1}$. Third, a mixture of both electrolytes, which consisted of (iii) 
$25 \mathrm{mmol} \mathrm{L}^{-1} \mathrm{Na}_{2} \mathrm{SO}_{4}+25 \mathrm{mmol} \mathrm{L}^{-1} \mathrm{NaCl}$ solutions in Milli-Q water with conductivity of $6.90 \mathrm{mS} \mathrm{cm}^{-1}$, was also evaluated.

Considering that real water matrices contain complex mixtures of inorganic species, artificial water matrices were prepared using a synthetic wastewater effluent composition reported elsewhere [25]. The synthetic wastewater effluent (iv) was prepared in Milli-Q water with conductivity of $2.25 \mathrm{mS} \mathrm{cm}{ }^{-1}$ using the following composition: $2.10 \mathrm{mmol} \mathrm{L}^{-1} \mathrm{KNO}_{3}$, $10.3 \mathrm{mmol} \mathrm{L}^{-1} \mathrm{NaCl}, 7.04 \mathrm{mmol} \mathrm{L}^{-1} \mathrm{Na}_{2} \mathrm{SO}_{4}$, and $1.5 \mathrm{mmol} \mathrm{L}^{-1} \mathrm{NH}_{4} \mathrm{Cl}$. Finally, real urban wastewater (v) was also subjected to electrochemical treatment; this effluent was collected after aerobic / anaerobic bacterial treatment from a wastewater treatment plant (WWTP) in the city of Bariri, São Paulo State, Brazil - the effluent was stored at $4{ }^{\circ} \mathrm{C}$ until its characterization (Table 1) and use.

Table 1. Physico-chemical characteristics of the real urban wastewater.

\begin{tabular}{ll}
\hline Physical Characteristics & Values \\
$\mathrm{pH}$ & 7.70 \\
Conductivity $\left(\mathrm{mS} \mathrm{cm}^{-1}\right)$ & 2.40 \\
Total organic carbon $(\mathrm{mg} \mathrm{C} \mathrm{L}$ & $-1)$ \\
Chemical Characteristics & 13.48 \\
Ammonia $\left(\mathrm{NH}_{4}^{+}\right)$ & Values $\left(\mathrm{mg} \mathrm{L}^{-1}\right)$ \\
Calcium $\left(\mathrm{Ca}^{2+}\right)$ & 5.81 \\
Magnesium $\left(\mathrm{Mg}^{2+}\right)$ & 30.94 \\
Potassium $\left(\mathrm{K}^{+}\right)$ & 6.07 \\
Sodium $\left(\mathrm{Na}^{+}\right)$ & 15.54 \\
Chloride $\left(\mathrm{Cl}^{-}\right)$ & 90.68 \\
Nitrate $\left(\mathrm{NO}_{3}^{-}\right)$ & 53.62 \\
Nitrite $\left(\mathrm{NO}_{2}^{-}\right)$ & 8.67 \\
Sulfate $\left(\mathrm{SO}_{4}^{2-}\right)$ & 0.98 \\
\hline
\end{tabular}




\subsection{Treatment of endocrine disruptors by EAOPs}

The bench-scale electrochemical assays were performed in a $150 \mathrm{~mL}$ electrochemical cell under controlled temperature of $25^{\circ} \mathrm{C}$. To perform the assays, commercial electrodes were used. A 2500 ppm boron-doped diamond (BDD) thin film doped on a Si substrate (acquired from NeoCoat) was used as anode and a PTFE gas diffusion electrode (supplied by Sainergy Fuel Cell) connected to a pure $\mathrm{O}_{2}$ line with a gas flow of $500 \mathrm{~mL} \mathrm{~min}{ }^{-1}$ was used as cathode. Both electrodes had a geometric area of $3.0 \mathrm{~cm}^{2}$ and were kept at an interelectrode gap distance of $1.0 \mathrm{~cm}$. Experiments were conducted galvanostatically under a fixed applied current density (j) using a Minipa MPS-3005B DC power supply coupled to Instrutemp ITMDB ITM 100 amperemeter and Instrutemp MDB-450 voltmeter. Before the experiments, the anode and cathode were activated for 60 minutes at $j$ of $100 \mathrm{~mA} \mathrm{~cm}^{-2}$ in $\mathrm{NaSO}_{4} 50 \mathrm{mmol}$ $\mathrm{L}^{-1}$ solution.

The EF and PEF treatments were performed using $0.5 \mathrm{mmol} \mathrm{L}^{-1} \mathrm{Fe}^{2+}$ as catalyst for the Fenton process. For the PEF treatment process, the solution was simultaneously illuminated using a 5W UVC lamp (Pen-Ray model 11SC-2.12) with irradiance of $19 \mathrm{~W} \mathrm{~m}^{-2}$. Different operating conditions were tested: $\mathrm{pH}=3,7$ and 10 (adjusted with dilute solution of $1 \mathrm{M}$ $\mathrm{H}_{2} \mathrm{SO}_{4}$ or $1 \mathrm{M} \mathrm{NaOH}$ ); applied current density $(j)=16.7,33.3$ and $66.7 \mathrm{~mA} \mathrm{~cm}{ }^{-2}$; initial concentration of BPA $=0.07,0.14$ and $0.28 \mathrm{mmol} \mathrm{L}^{-1}$, with the following TOC values, 12.5, 25 and 50 ppm, respectively.

The optimized operating conditions $\left(j=33.3 \mathrm{~mA} \mathrm{~cm}{ }^{-2} ; \mathrm{pH}=3\right.$, and $[\mathrm{BPA}]=0.14 \mathrm{mmol}$ $\mathrm{L}^{-1}$ ) were used for the removal of different endocrine disruptors in urban wastewater effluent from a wastewater treatment plant. The urban wastewater effluent was contaminated with $0.14 \mathrm{mmol} \mathrm{L}^{-1} \mathrm{BPA}$, MetP and PAC, which were to be removed by three electrochemical 
advanced oxidation processes (EAOPs): Electrogenerated $\mathrm{H}_{2} \mathrm{O}_{2}$ coupled to electrochemical oxidation $\left(\mathrm{EO}-\mathrm{H}_{2} \mathrm{O}_{2}\right), \mathrm{EF}$, and PEF processes. The electrical energy per order $(\mathrm{EE} / \mathrm{O})$ for the processes was calculated based on Eq. $7[24,26]$.

$$
E E / O\left(k_{W h m^{-3}} \text { order }^{-1}\right)=\frac{6.39 \times 10^{-4} P}{V_{s} k_{1}}
$$

where $6.39 \times 10^{-4}$ is the conversion factor $(1 \mathrm{~h} / 3600 \mathrm{~s} / 0.4343)$; $P$, which, depending on the process, can be the average of the cell potential $\left(P_{\text {cell }}\right)$ or the sum of $P_{\text {cell }}$ with the potential of the UV lamp ( $\left.P_{\text {lamp }}\right)$ in $\mathrm{V} ; V_{s}$ is the volume of the solution in $\mathrm{L}$; and $k_{1}$ is the pseudo-first order kinetic constant in $\mathrm{s}^{-1}$.

\subsection{Analytical determinations}

The $\mathrm{pH}$ and conductivity were measured using ION pHB500 meter and digimed DM3, respectively.

The accumulated concentration of $\mathrm{H}_{2} \mathrm{O}_{2}$ was determined by the molybdate complex method using a Shimadzu UV-1900 spectrophotometer. The absorbance of the colored complex formed with peroxide and $\left(\mathrm{NH}_{4}\right)_{6} \mathrm{Mo}_{7} \mathrm{O}_{24}$ was measured at wavelength $(\lambda)$ of 350 $\mathrm{nm}$ [27]. The current efficiency $\left(C E_{\mathrm{H}_{2} \mathrm{O}_{2}}\right)$ associated with the generation of the accumulated $\mathrm{H}_{2} \mathrm{O}_{2}$ follows the Faraday's law described by Eq. 8 below.

$$
C E_{\mathrm{H}_{2} \mathrm{O}_{2}}(\%)=\frac{2 \mathrm{~F} \mathrm{C}_{\mathrm{H}_{2} \mathrm{O}_{2}} \mathrm{~V}_{\mathrm{s}}}{I t} \times 100
$$

where 2 corresponds to the number of electrons required for $\mathrm{O}_{2}$ reduction toward $\mathrm{H}_{2} \mathrm{O}_{2}$ production; $F$ stands for the Faraday constant $\left(96,487 \mathrm{C} \mathrm{mol}^{-1}\right) ; \mathrm{C}_{\mathrm{H}_{2} \mathrm{O}_{2}}$ represents the $\mathrm{H}_{2} \mathrm{O}_{2}$ 
concentration in mol L-1; $V_{s}$ is the volume of the solution in $\mathrm{L} ; I$ stands for applied current intensity in $\mathrm{A}$; and $t$ is the reaction time in seconds.

The BPA concentration was monitored using a Shimadzu High Performance Liquid Chromatography (HPLC) model LC-20 AT, equipped with a Phenomenex Luna C18 (250 x $4.6 \mathrm{~mm}, 5 \mu \mathrm{m})$ column and a Supelcosil C18 (4 x $3.0 \mathrm{~mm}$ i.d.) pre-column at $35^{\circ} \mathrm{C}$. The mobile phase employed consisted of a mixture of acetonitrile/water in the ratio 60:40 (v/v). The detection of the compound was performed using SPD-20A UV detector at wavelength of $280 \mathrm{~nm}$, and well-defined peaks were observed in the chromatogram at retention time $\left(t_{r}\right)$ of $4.7 \mathrm{~min}$. Total organic carbon (TOC) was evaluated using Shimadzu TOC-VCPN equipment. TOC removal percentage was calculated based on Eq. 9.

TOC removal $(\%)=\frac{T O C_{0}-T O C_{f}}{T O C_{0}} \times 100$

where $\mathrm{TOC}_{0}$ and $\mathrm{TOC}_{\mathrm{f}}$ represent the total organic carbon at the initial and final time of the process $\left(\mathrm{mg} \mathrm{C} \mathrm{L}^{-1}\right)$, respectively. The current efficiency related to mineralization (MCE) was calculated using Eq. 10:

$$
\operatorname{MCE}(\%)=\frac{n F V_{s} \Delta(\text { TOC })_{\exp }}{4.32 \times 10^{7} \mathrm{mIt}} \times 100
$$

where Vs represents the volume of the solution (L), $\Delta(\mathrm{TOC})_{\exp }$ is the difference between $\mathrm{TOC}_{0}$ and TOC at time $t\left(\mathrm{mg} \mathrm{C} \mathrm{L}^{-1}\right), 4.32 \times 10^{7}$ is the conversion factor $\left(3,600 \mathrm{~s} \mathrm{~h}^{-1} \times 12,000\right.$ $\left.\mathrm{mg} \mathrm{C} \mathrm{mol}{ }^{-1}\right), m$ is the number of carbon atoms that belong to the BPA molecule $(m=15)$, 
and $t$ is specific time (h). When one considers the theoretical and total mineralization of BPA, one will find that the number of electrons $(n)$ is 72 [13] (Eq. 11):

$$
\mathrm{C}_{15} \mathrm{H}_{16} \mathrm{O}_{2}+28 \mathrm{H}_{2} \mathrm{O} \rightarrow 15 \mathrm{CO}_{2}+72 \mathrm{H}^{+}+72 \mathrm{e}^{-}
$$

The concentration of inorganic ions was determined by ion-chromatography using 850 Profissional IC ion chromatograph coupled to a 940 Professional IC module (Metrohm). The amount of each sample injection employed was $20 \mu \mathrm{L}$. The cationic species were analyzed using a Metrosep C4 column $(150 \mathrm{~mm} / 4.0 \mathrm{~mm})$ and a Metrosep C4 Guardian/4.0 pre-column at $30{ }^{\circ} \mathrm{C}$. The following was used as eluent: $1.7 \mathrm{mmol} \mathrm{L}^{-1}$ nitric acid $/ 0.7 \mathrm{mmol} \mathrm{L}{ }^{-1}$ dipicolinic acid at $0.9 \mathrm{~mL} \mathrm{~min}^{-1}$. Analytical curves with concentrations ranging from 0 to $25 \mathrm{mg} \mathrm{L}^{-1}\left(\mathrm{R}^{2}\right.$ $>0.99)$ were constructed for the following cationic species (retention times): $\mathrm{Na}^{+}\left(t_{r}=5.20\right.$ $\min ), \mathrm{NH}_{4}^{+}\left(t_{r}=5.80 \mathrm{~min}\right), \mathrm{K}^{+}\left(t_{r}=7.70 \mathrm{~min}\right), \mathrm{Ca}^{2+}\left(t_{r}=16.00 \mathrm{~min}\right)$, and $\mathrm{Mg}^{2+}\left(t_{r}=18.95\right.$ min). The anionic species were analyzed in a Metrosep A Supp 5 column $(150 \mathrm{~mm} / 4.0 \mathrm{~mm})$ and a Metrosep A Supp 5 Guardian/4.0 pre-column at $30^{\circ} \mathrm{C}$, using an eluent composed of $3.2 \mathrm{mmol} \mathrm{L}^{-1} \mathrm{Na}_{2} \mathrm{CO}_{3} / 1.0 \mathrm{mmol} \mathrm{L}^{-1} \mathrm{NaHCO}_{3}$ at $0.7 \mathrm{~mL} \mathrm{~min}{ }^{-1}$. An analytical curve with concentrations ranging from 0 to $100 \mathrm{mg} \mathrm{L}^{-1}$ was constructed for each of the following anionic species: $\mathrm{Cl}^{-}\left(t_{r}=5.45 \mathrm{~min}\right), \mathrm{NO}_{2}^{-}\left(t_{r}=6.60 \mathrm{~min}\right), \mathrm{ClO}_{2}^{-}\left(t_{r}=4.30 \mathrm{~min}\right), \mathrm{ClO}_{3}{ }^{-}\left(t_{r}=\right.$ $8.00 \mathrm{~min}), \mathrm{NO}_{3}{ }^{-}\left(t_{r}=9.75 \mathrm{~min}\right), \mathrm{PO}_{4}^{3-}\left(t_{r}=13.50 \mathrm{~min}\right)$, and $\mathrm{SO}_{4}{ }^{2-}(15.70 \mathrm{~min})$. The carboxylic acids generated were analyzed using the ion chromatograph mentioned previously. The following was used for the conduct of the analysis - separation column: Metrosep Organic Acids $(250 \mathrm{~mm} / 7.8 \mathrm{~mm})$ from Metrohm; solvent: a diluted $\mathrm{H}_{2} \mathrm{SO}_{4}$ solution $\left(0.75 \mathrm{mmol} \mathrm{L}^{-1}\right)$; and suppressor: $\mathrm{NaCl} 50 \mathrm{mmol} \mathrm{L}{ }^{-1}$. Analytical curves of different carboxylic acids were constructed for concentrations ranging between $0-100 \mathrm{mg} \mathrm{L}^{-1}\left(\mathrm{R}^{2}>0.99\right)$ using the following: 
oxalic acid $\left(t_{r}=7.60 \mathrm{~min}\right)$, malic acid $\left(t_{r}=9.85 \mathrm{~min}\right)$, acetic acid $\left(t_{r}=13.60 \mathrm{~min}\right)$, and formic $\operatorname{acid}\left(t_{r}=15.25 \mathrm{~min}\right)$.

\section{Results and discussion}

\subsection{Generation and accumulation of $\mathrm{H}_{2} \mathrm{O}_{2}$ in media of different complexity}

Sulfate and chloride are ionic species which are commonly present in wastewater. These inorganic ions provide the essential conductivity required for the conduct of electrochemical treatments. Apart from sulfate and chloride, real wastewater also contains other ions and compounds, and this makes the matrix more complex to handle. Fig. 1a illustrates the effect of the electrolyte on the accumulation of electrogenerated $\mathrm{H}_{2} \mathrm{O}_{2}$ during electrolysis conducted for a period of $360 \mathrm{~min}$ in an undivided cell at $\mathrm{pH} 3.0$, with current density of $33.3 \mathrm{~mA} \mathrm{~cm}$. As can be observed, regardless of the medium applied, there is a progressive accumulation of $\mathrm{H}_{2} \mathrm{O}_{2}$ caused by its continuous electrogeneration from oxygen reduction via reaction (2), which is followed by the occurrence of a plateau after $240 \mathrm{~min}$ of treatment. This behavior is attributed to the simultaneous degradation of accumulated $\mathrm{H}_{2} \mathrm{O}_{2}$ through its oxidation at the anode or further reduction to water at the cathode, which leads to the generation of a pseudosteady concentration. Despite the similarities observed for sulfate and chloride media, there is a marked difference in the maximum concentration obtained at the steady state. When sulfate is used as medium, a relatively higher $\mathrm{H}_{2} \mathrm{O}_{2}\left(26.6 \mathrm{mmol} \mathrm{L}^{-1}\right)$ concentration is obtained compared to that obtained when chloride is used as medium $\left(21.2 \mathrm{mmol} \mathrm{L}^{-1}\right)$. The relatively lower $\mathrm{H}_{2} \mathrm{O}_{2}$ accumulation observed in chloride media can be attributed to the role played by electrogenerated active chlorine species in the process. The oxidation of chloride ion on the surface of the anode leads to the generation of chlorine $\left(\mathrm{Cl}_{2(\mathrm{aq})}, \mathrm{E}^{\circ}=1.36 \mathrm{~V}\right.$ vs $\left.\mathrm{SHE}\right)$ based on Eq. (12). The hydrolysis of chlorine yields hypochlorous acid $\left(\mathrm{HClO}, \mathrm{E}^{\circ}=1.49 \mathrm{~V}\right.$ vs $\left.\mathrm{SHE}\right)$ 
and $\mathrm{Cl}^{-}$(Eq. 13) [28]. The $\mathrm{pH}$ plays an important role in the distribution of active chlorine species by defining their speciation. For instance, $\mathrm{HClO}$ has an acid-base equilibrium described in Eq. (14), with $\mathrm{pKa}=7.55$, which may lead to the preferential accumulation of the weaker oxidant hypochlorite $\left(\mathrm{OCl}^{-}, \mathrm{E}^{\circ}=0.89 \mathrm{~V}\right.$ vs SHE) [29]. Electrogenerated active chlorine species are strong oxidants that can scavenge $\mathrm{H}_{2} \mathrm{O}_{2}$ [30]. The experiment conducted using mixed electrolyte composition of $25 \mathrm{mmol} \mathrm{L}^{-1} \mathrm{Na}_{2} \mathrm{SO}_{4}$ and $25 \mathrm{mmol} \mathrm{L}^{-1} \mathrm{NaCl}$ generated a maximum accumulated $\mathrm{H}_{2} \mathrm{O}_{2}$ of $23.9 \mathrm{mmol} \mathrm{L}^{-1}$ between the individual electrolytes. This result is in agreement with the scavenging role of active chlorine species which are accumulated at a lower rate for lower concentrations of chloride.

$$
\begin{array}{ll}
2 \mathrm{Cl}^{-} \rightarrow \mathrm{Cl}_{2(\mathrm{aq})}+2 \mathrm{e}^{-} & \mathrm{pH}<3 \\
\mathrm{Cl}_{2(\mathrm{aq})}+\mathrm{H}_{2} \mathrm{O} \rightarrow \mathrm{HClO}+\mathrm{Cl}^{-}+\mathrm{H}^{+} & 3<\mathrm{pH}<8 \\
\mathrm{HClO} \rightleftarrows \mathrm{OCl}^{-}+\mathrm{H}^{+} & \mathrm{pH}>8
\end{array}
$$



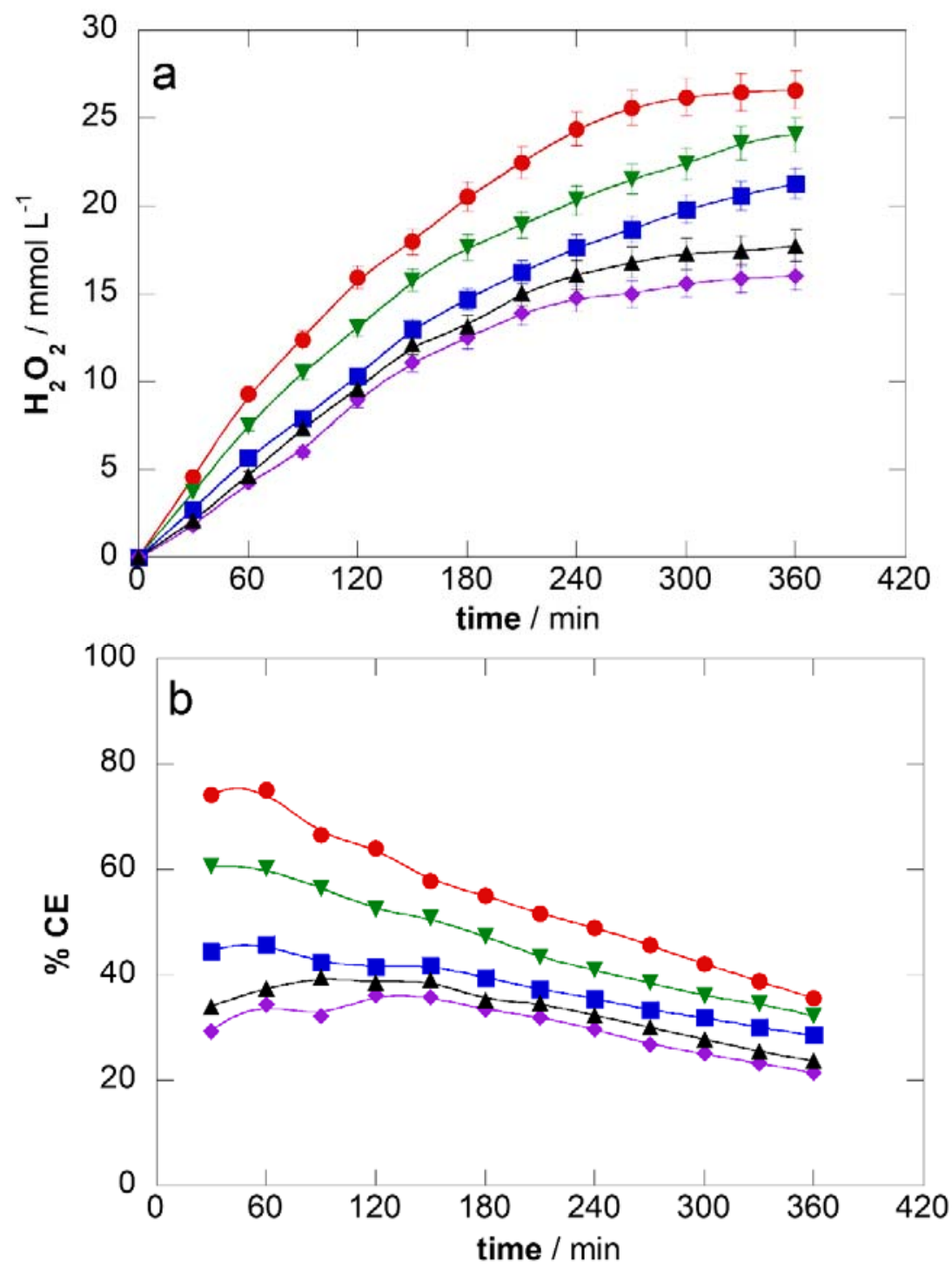

Fig. 1. a) Accumulation and b) current efficiency of $\mathrm{H}_{2} \mathrm{O}_{2}$ over time. Operating conditions: $\mathrm{EO}-\mathrm{H}_{2} \mathrm{O}_{2}$ at $\mathrm{pH} 3.0$ and temperature of $25^{\circ} \mathrm{C}$ using a stirred undivided cell with BDD anode and carbon-PTFE cathode, at current density $(j)=33.3 \mathrm{~mA} \mathrm{~cm}{ }^{-2}$, in different media: (○) $50 \mathrm{mmol} \mathrm{L}^{-1} \mathrm{Na}_{2} \mathrm{SO}_{4},(\nabla) 25 \mathrm{mmol} \mathrm{L}^{-1} \mathrm{Na}_{2} \mathrm{SO}_{4}+25 \mathrm{mmol} \mathrm{L}^{-1} \mathrm{NaCl}$, ( $\square$ ) $50 \mathrm{mmol}$ $\mathrm{L}^{-1} \mathrm{NaCl},(\boldsymbol{\Delta})$ synthetic effluent, and $(\diamond)$ real wastewater. 
With regard to the electrogeneration and accumulation of $\mathrm{H}_{2} \mathrm{O}_{2}$ for the simulated and real effluents, lower $\mathrm{H}_{2} \mathrm{O}_{2}$ concentrations were obtained - approximately $17.6 \mathrm{mmol} \mathrm{L}^{-1}$ and 16.1 mmol L $\mathrm{L}^{-1}$, respectively, compared to the previous experiments using $\mathrm{Na}_{2} \mathrm{SO}_{4}, \mathrm{Na}_{2} \mathrm{SO}_{4}+$ $\mathrm{NaCl}$, and $\mathrm{NaCl}$. The increase in complexity of the medium contributed toward a slight decrease in concentration of the oxidant generated due to the increased probability of the number of parasitic reactions that were expected to occur as a result of the additional inorganic ions and the natural organic matter that were present in the medium.

The evaluation of the Faradaic efficiency provides a quantitative understanding of the impact of scavenging oxidants in the solution investigated. Fig. 1b illustrates the gradual decrease of overall efficiency over time of the electrogeneration of $\mathrm{H}_{2} \mathrm{O}_{2}$ due to the coexistence of parasitic reactions that consume this oxidant (Eqs. 15-19) [30-32]. The most noticeable difference associated with the electrolyte composition can be observed at the beginning of the experiments where the $C E_{\mathrm{H}_{2} \mathrm{O}_{2}}$ values were $74.1 \%$ for $\mathrm{Na}_{2} \mathrm{SO}_{4}, 60.6 \%$ for $\mathrm{Na}_{2} \mathrm{SO}_{4}+\mathrm{NaCl}, 44.5 \%$ for $\mathrm{NaCl}, 34.2 \%$ for the synthetic effluent, and $29.3 \%$ for the real wastewater. Note that this implies a noticeable 2.5-fold decrease in $\mathrm{H}_{2} \mathrm{O}_{2}$ electrogeneration efficiency in the real water samples, which is attributed to the constituents of this effluent, compared to the solution containing only $\mathrm{Na}_{2} \mathrm{SO}_{4}$. This dramatic decrease in $C E_{\mathrm{H}_{2} \mathrm{O}_{2}}$ (loss of about $45 \%$ ) may undermine the performance of $\mathrm{H}_{2} \mathrm{O}_{2}$-based AOPs and should be considered during the implementation of the technology in industrial scale production. Fortunately, the experimental results show that the amount of electrogenerated $\mathrm{H}_{2} \mathrm{O}_{2}$ required for the degradation of organic pollutants can be sustained independently of the supporting electrolyte employed.

$$
\mathrm{BDD}+\mathrm{H}_{2} \mathrm{O}_{2} \rightarrow \mathrm{BDD}\left(\mathrm{HO}_{2}^{\bullet}\right)+\mathrm{H}^{+}+\mathrm{e}^{-}
$$




$$
\begin{aligned}
& \mathrm{H}_{2} \mathrm{O}_{2}+2 \mathrm{H}^{+}+2 \mathrm{e}^{-} \rightarrow 2 \mathrm{H}_{2} \mathrm{O} \\
& \mathrm{H}_{2} \mathrm{O}_{2}+\mathrm{Cl}_{2} \rightarrow \mathrm{O}_{2}+2 \mathrm{H}^{+}+2 \mathrm{Cl}^{-} \\
& \mathrm{H}_{2} \mathrm{O}_{2}+\mathrm{HOCl} \rightarrow \mathrm{O}_{2}+\mathrm{H}_{2} \mathrm{O}+\mathrm{H}^{+}+\mathrm{Cl}^{-} \\
& \mathrm{H}_{2} \mathrm{O}_{2}+\mathrm{OCl}^{-} \rightarrow \mathrm{O}_{2}+\mathrm{H}_{2} \mathrm{O}+\mathrm{Cl}^{-}
\end{aligned}
$$

\subsection{Impacts of water matrix on the efficiency of EAOPs in the removal of endocrine disruptors}

Bisphenol A (BPA) is a common endocrine disruptor found in natural water bodies. The present work investigated the effect of water matrix composition on the degradation of 0.14 mmol L-1 BPA through the application of different EAOPs under comparable conditions of pH 3.0 and applied density of $33.3 \mathrm{~mA} \mathrm{~cm}^{-2}$.

The nature of the EAOPs employed has a direct impact on the kinetics of BPA degradation (decay) as can be noted in Fig. 2. Slower degradation rates were observed for the mass transfer limited EO- $\mathrm{H}_{2} \mathrm{O}_{2}$ process, while the Fenton-based processes recorded 4.025 times faster BPA removal (Fig. 2 - b, d, f). Here, one will notice the remarkably faster removal rate observed between the treatment processes where the electrolysis time of $60 \mathrm{~min}$ for the EO- $\mathrm{H}_{2} \mathrm{O}_{2}$ process was reduced down to roughly $10 \mathrm{~min}$ for electrochemically driven Fenton processes (Fig. 2a, c, e). These results point to the key role played by two factors in accelerating the degradation of BPA: i) the in situ generation of homogeneous ${ }^{\bullet} \mathrm{OH}$ radicals, derived from the Fenton reaction (3); and ii) the role of UVC light in the photolytic process described in reaction (20). The results obtained here are in agreement with the findings published previously in the literature which showed that the application of electro-Fenton techniques led to higher removal of organic persistent pollutants from water matrices $[33,34]$. 
Even though similar patterns of behavior were observed for different water matrices when the EAOPs were compared under certain conditions, a closer look at the data revealed that the water matrix played a major role in the kinetics of BPA removal for each individual electrochemically-driven technique. These differences are more noticeable for the $\mathrm{EO}-\mathrm{H}_{2} \mathrm{O}_{2}$ process where different electrolytes greatly influenced the degradation kinetics. The degradation of BPA via the EO- $\mathrm{H}_{2} \mathrm{O}_{2}$ treatment process in the presence of $\mathrm{Na}_{2} \mathrm{SO}_{4}$ led to a gradual decrease of BPA concentration, where 39.6\% BPA removal was obtained after 60 min of treatment. For purposes of comparison, the presence of chloride anion enhanced BPA removal with a sharp increase in the contaminant decay. For the treatments conducted using $\mathrm{Na}_{2} \mathrm{SO}_{4}+\mathrm{NaCl}$ and $\mathrm{NaCl}$, the complete removal of BPA was achieved after 30 and $60 \mathrm{~min}$ of treatment. The corresponding degradation rate constants $\left(k_{1}\right)$ obtained under the different media employed were $2.12 \times 10^{-4} \mathrm{~s}^{-1}\left(\mathrm{R}^{2}=0.998\right), 9.22 \times 10^{-4} \mathrm{~s}^{-1}\left(\mathrm{R}^{2}=0.993\right)$, and $1.98 \times 10^{-3} \mathrm{~s}^{-1}$ $\left(\mathrm{R}^{2}=0.996\right)$, for $\mathrm{Na}_{2} \mathrm{SO}_{4}, \mathrm{NaCl}$, and $\mathrm{Na}_{2} \mathrm{SO}_{4}+\mathrm{NaCl}$, respectively. This result can be attributed to the presence of sulfate and chloride species in the water matrix and their possible coelectrogeneration of additional oxidants apart from ${ }^{\bullet} \mathrm{OH}$ : peroxydisulfate $\left(\mathrm{S}_{2} \mathrm{O}_{8}{ }^{2-}, \mathrm{E}^{0}=2.01\right.$ $\mathrm{V}$ vs SHE, Eq. 21) and active chlorine species (Eqs. 12-14). A comparison between peroxydisulfate and active chlorine species shows that the latter has relatively greater oxidizing power [9]. It is worth noting that, compared to ${ }^{\bullet} \mathrm{OH}$ radicals, these extra oxidants - peroxydisulfate and active chlorine species, have weaker oxidation potentials, and have mainly distinct homogeneous character. These electrogenerated oxidants are yielded in the bulk of the solution. 


$$
\mathrm{SO}_{4}^{2-}+\mathrm{SO}_{4}^{2-} \rightarrow \mathrm{S}_{2} \mathrm{O}_{8}{ }^{2-}+2 \mathrm{e}^{-}
$$

Although the presence of sulfate and chloride improves the pollutant degradation, depending on the concentration of these species, they may also act as scavengers of ${ }^{\bullet} \mathrm{OH}$ radicals (Eqs. 22 - 26) [35]. This deleterious effect is observed for the experiment with 50 mmol L-1 $\mathrm{NaCl}$. The $\mathrm{Cl}^{-}$concentration evolution was followed over time and its conversion occurred as follows: $4.5 \%, 9.3 \%$ and $22.1 \%$ for the $\mathrm{NaCl}, \mathrm{Na}_{2} \mathrm{SO}_{4}+\mathrm{NaCl}$, and synthetic effluent water matrices, respectively. Based on the results obtained, the conversion of higher amount of $\mathrm{Cl}^{-}$implied the generation of greater amount of active chlorine species.

$$
\begin{aligned}
& \mathrm{SO}_{4}{ }^{2-}+{ }^{\bullet} \mathrm{OH} \rightarrow \mathrm{SO}_{4}{ }^{-\bullet}+\mathrm{OH}^{-} \\
& \mathrm{Cl}^{-}+\bullet \mathrm{OH} \rightleftarrows \mathrm{ClO}^{-}+\mathrm{H}^{+}+\mathrm{e}^{-} \\
& \mathrm{ClO}^{-}+{ }^{\bullet} \mathrm{OH} \rightleftarrows \mathrm{ClO}_{2}^{-}+\mathrm{H}^{+}+\mathrm{e}^{-} \\
& \mathrm{ClO}_{2}{ }^{-}+{ }^{\bullet} \mathrm{OH} \rightleftarrows \mathrm{ClO}_{3}{ }^{-}+\mathrm{H}^{+}+\mathrm{e}^{-} \\
& \mathrm{ClO}_{3}{ }^{-}+{ }^{\bullet} \mathrm{OH} \rightleftarrows \mathrm{ClO}_{4}^{-}+\mathrm{H}^{+}+\mathrm{e}^{-}
\end{aligned}
$$

The fundamental understanding derived from these experiments on simple electrolytes helped interpret the results obtained from the treatment of the simulated and real wastewater matrices (Fig. 2a). Apart from the effect of inorganic electrolytes, one also needs to point out the effect of organic matter present in real water samples (see Table 1). Organic matter that naturally exists in water effluents compete with the target pollutant (i.e., BPA) for the electrogenerated oxidants (e.g., ${ }^{\bullet} \mathrm{OH}$ radicals, active chlorine species, etc.), and this contributes to the decline in the removal efficiency. This undesired effect was found to be evident when the rate of BPA degradation in the real wastewater was compared with that observed for the simulated wastewater effluent in the absence of the organic species. 
The results obtained from the experiments also showed that other inorganic compounds, such as potassium, nitrate, and ammonia, did not exert any significant influence on the decay of the contaminant under the $\mathrm{EO}-\mathrm{H}_{2} \mathrm{O}_{2}$ treatment technique.

Similar patterns of behavior were observed for the $\mathrm{EO}-\mathrm{H}_{2} \mathrm{O}_{2}$ treatment mechanism with regard to the pollutant mineralization in terms of total organic carbon (TOC) removal (Table 2). Discrete TOC removal rates ranging between $14.8-31.5 \%$ were obtained after 60 min of treatment by $\mathrm{EO}-\mathrm{H}_{2} \mathrm{O}_{2}$; this range of TOC removal rates is commonly observed for electrochemical oxidation processes. This outcome can be attributed to the mass transfer limitation and the quantity of intermediate compounds generated which can have a more recalcitrant character than the compounds initially present in the wastewater effluent. Interestingly, the highest TOC removal (31.5\%) was obtained under the treatment using the simulated wastewater effluent. The higher degree of mineralization obtained under the treatment with simulated wastewater effluent may be attributed to the solution composition. The synthetic medium contains $\mathrm{NO}_{3}{ }^{-}$and $\mathrm{NH}_{4}{ }^{+}$, in addition to sulfate and chloride ions. On the one hand, the $\mathrm{NH}_{4}{ }^{+}$cation has negligible impact on the mineralization of pollutants (the aspects related to its reactivity with active chlorine species will be discussed in detail later). On the other hand, according to recent literature reports [36], the use of water matrices with $\mathrm{NO}_{3}{ }^{-}$can yield a higher TOC removal due to $\mathrm{N}$-containing species produced from $\mathrm{NO}_{3}{ }^{-}$ electro-reduction which may contribute toward the mineralization of by-products, leading to higher mineralization. Finally, the result obtained for mineralization current efficiency estimated based on Eq. 10 indicated the following in terms of process efficiency: Synthetic effluent $>\mathrm{NaCl}+\mathrm{Na}_{2} \mathrm{SO}_{4}>\mathrm{NaCl}>\mathrm{Na}_{2} \mathrm{SO}_{4}$. This result is in agreement with the results obtained for TOC removal shown in Table 2. 
The results obtained related to the effect of the composition of the water matrix showed comparable patterns of behavior for the electrochemically-driven Fenton processes. The contaminant degradation was found to occur faster in the simulated effluent $\left(k_{1}=7.23 \times 10^{-3} \mathrm{~s}^{-}\right.$ $\left.{ }^{1}-\mathrm{EF}, k_{1}=9.05 \times 10^{-3} \mathrm{~s}^{-1}-\mathrm{PEF}\right)$, and this was closely followed by $\mathrm{Na}_{2} \mathrm{SO}_{4}+\mathrm{NaCl}\left(k_{1}=5.85 \times 10^{-}\right.$ $\left.{ }^{3} \mathrm{~s}^{-1}-\mathrm{EF}, k_{1}=6.91 \times 10^{-3} \mathrm{~s}^{-1}-\mathrm{PEF}\right)$, real wastewater $\left(k_{1}=5.11 \times 10^{-3} \mathrm{~s}^{-1}-\mathrm{EF}, k_{1}=5.93 \times 10^{-3} \mathrm{~s}^{-1}\right.$ - PEF), and $\mathrm{Na}_{2} \mathrm{SO}_{4}\left(k_{1}=4.45 \times 10^{-3} \mathrm{~s}^{-1}-\mathrm{EF}, k_{1}=5.34 \times 10^{-3} \mathrm{~s}^{-1}-\mathrm{PEF}\right)$ (Figs. $2-\mathrm{c}, \mathrm{d}, \mathrm{e}, \mathrm{f}$, and Table 2). The slightly faster degradation kinetics of the endocrine disruptor observed under the PEF treatment technique can be attributed to the role played by irradiation in the process. The use of UVC irradiation can yield additional ${ }^{\bullet} \mathrm{OH}$ radicals from $\mathrm{H}_{2} \mathrm{O}_{2}$ photolysis (Eq. 28). Furthermore, UVC irradiation can activate other electrogenerated oxidants, which can, in turn, lead to the formation of higher oxidizing species, such as sulfate radical $\mathrm{SO}_{4}^{-\bullet}$ based on reaction (27) or chlorine radical $\left(\mathrm{Cl}^{\bullet}\right)$ via reactions (28) and (29).

$$
\begin{aligned}
& \mathrm{S}_{2} \mathrm{O}_{8}{ }^{2-}+\mathrm{h} v \rightarrow 2 \mathrm{SO}_{4}^{-\bullet} \\
& \mathrm{HOCl}+\mathrm{h} v \rightarrow{ }^{\bullet} \mathrm{OH}+\mathrm{Cl}^{\bullet} \\
& \mathrm{ClO}^{-}+\mathrm{h} v \rightarrow \mathrm{O}^{-\bullet}+\mathrm{Cl}^{\bullet}
\end{aligned}
$$

The TOC removal rates for the matrices investigated saw between 1.2-1.8 fold increase for EF and between 1.4-2.4 fold increase for PEF compared to $\mathrm{EO}-\mathrm{H}_{2} \mathrm{O}_{2}$ (Table 2). The higher mineralization percentage obtained for the PEF process is related to photodecarboxylation reactions induced by light irradiation based on reaction (6). In terms of BPA mineralization, the superior mineralization efficiency observed for the Fenton-based processes over the EO- $\mathrm{H}_{2} \mathrm{O}_{2}$ process was also reflected in the slightly higher MCE values obtained for the former, which ranged between $10.9-17.7 \%$ (Table 2). 
The type of water matrix and the electrochemical process suitable for the treatment of endocrine disruptors (EDs) are key elements that need to be considered when one seeks to obtain high rates of degradation. With that in mind, the next step of this study aimed to elucidate the applicability of EAOPs in the treatment of a mixture of EDs in real matrices.
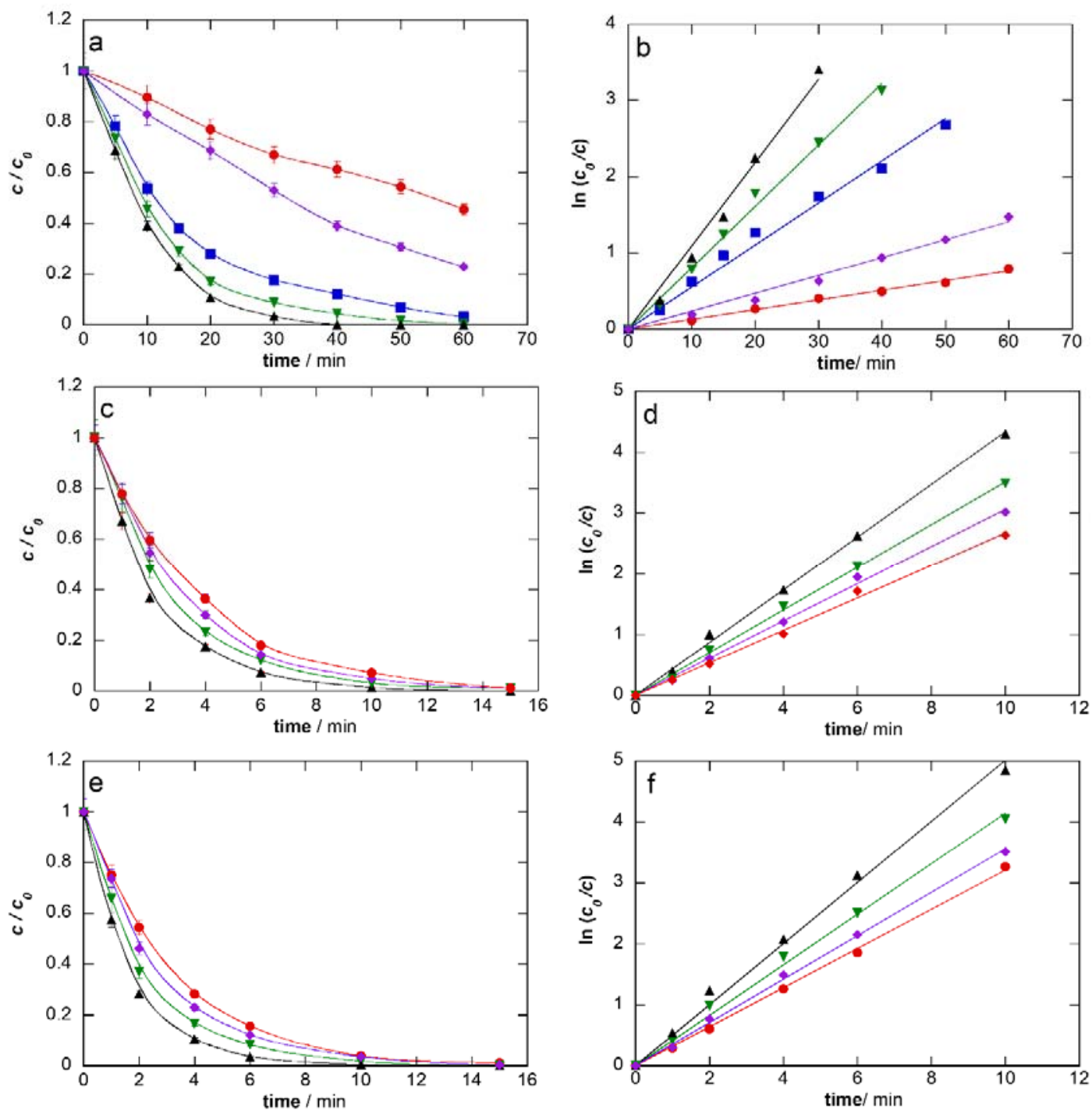

Fig. 2. Normalized BPA concentration decay over time (a, c, d) and corresponding pseudo-first-order kinetic analysis (b, d, f) for EO- $\mathrm{H}_{2} \mathrm{O}_{2}(a, b)$, EF (c, d) and PEF (e, f) processes, respectively. Operating conditions: a stirred undivided cell with BDD anode and carbon-PTFE cathode, with $\mathrm{pH}$ of $3.0, j=33.3 \mathrm{~mA} \mathrm{~cm}{ }^{-2}$, and temperature of $25^{\circ} \mathrm{C}$, using 
different media (○) $50 \mathrm{mmol} \mathrm{L}^{-1} \mathrm{Na}_{2} \mathrm{SO}_{4}$, ( $) 25 \mathrm{mmol} \mathrm{L}^{-1} \mathrm{Na}_{2} \mathrm{SO}_{4}+25 \mathrm{mmol} \mathrm{L}^{-1} \mathrm{NaCl}$, (ם) $50 \mathrm{mmol} \mathrm{L}^{-1} \mathrm{NaCl},(\boldsymbol{\Delta})$ synthetic wastewater effluent and $(\diamond)$ real wastewater.

Table 2. Key fitted and calculated parameters obtained from the experiments using $\mathrm{EO}-\mathrm{H}_{2} \mathrm{O}_{2}$, $\mathrm{EF}$ and PEF for the oxidation of $0.14 \mathrm{mmol} \mathrm{L}^{-1}$ bisphenol $\mathrm{A}$ in different media at $\mathrm{pH} 3$ and current density of $33.3 \mathrm{~mA} \mathrm{~cm}^{-2}$.

\begin{tabular}{|c|c|c|c|c|}
\hline Experiment & $k_{1} \times 10^{-3} / \mathrm{s}^{-1}$ & $\mathbf{R}^{2}$ & $\begin{array}{l}\text { TOC removal / } \\
\% *\end{array}$ & MCE / \% \\
\hline \multicolumn{5}{|l|}{$\mathrm{EO}-\mathrm{H}_{2} \mathrm{O}_{2}$} \\
\hline $\mathrm{Na}_{2} \mathrm{SO}_{4}$ & 0.212 & 0.998 & 14.8 & 5.95 \\
\hline $\mathrm{NaCl}$ & 0.922 & 0.993 & 22.8 & 9.13 \\
\hline $\mathrm{Na}_{2} \mathrm{SO}_{4}+\mathrm{NaCl}$ & 1.34 & 0.997 & 28.3 & 11.4 \\
\hline Simulated & 1.82 & 0.995 & 31.5 & 12.7 \\
\hline Real** & 0.391 & 0.992 & 18.3 & - \\
\hline \multicolumn{5}{|l|}{ EF } \\
\hline $\mathrm{Na}_{2} \mathrm{SO}_{4}$ & 4.45 & 0.993 & 27.2 & 10.9 \\
\hline $\mathrm{Na}_{2} \mathrm{SO}_{4}+\mathrm{NaCl}$ & 5.85 & 0.994 & 35.5 & 12.9 \\
\hline Simulated & 7.23 & 0.992 & 38.7 & 15.6 \\
\hline Real** & 5.11 & 0.997 & 28.6 & - \\
\hline \multicolumn{5}{|l|}{ PEF } \\
\hline $\mathrm{Na}_{2} \mathrm{SO}_{4}$ & 5.34 & 0.995 & 35.1 & 14.1 \\
\hline $\mathrm{Na}_{2} \mathrm{SO}_{4}+\mathrm{NaCl}$ & 6.91 & 0.993 & 40.1 & 16.4 \\
\hline Simulated & 9.05 & 0.998 & 44.2 & 17.7 \\
\hline Real** & 5.93 & 0.992 & 35.4 & - \\
\hline
\end{tabular}

*After 60 min of treatment.

** $\mathrm{TOC}_{0}=38 \mathrm{mg} \mathrm{C} \mathrm{L}^{-1}$ 


\subsection{Electrochemical treatment of real urban wastewater containing a mixture of endocrine disruptors}

Polluted waters may contain more than one recalcitrant endocrine disruptor. A more complex matrix is certainly more complicated to handle during the treatment process. Figure 3 shows the impact of coexisting pollutants methyl paraben (MeP) and paracetamol (PAC) in the degradation of BPA. Looking at Figs. 3a and 3b, one will observe that the degradation kinetics of BPA decreased significantly $(2.4-3.0 x)$ in this real wastewater medium under the application of the EAOPs. The coexistence of persistent organic pollutants decreased the kinetic rate of BPA removal under the $\mathrm{EO}-\mathrm{H}_{2} \mathrm{O}_{2}$ treatment process from $3.91 \times 10^{-4} \mathrm{~s}^{-1}$ in the real effluent down to $1.64 \times 10^{-4} \mathrm{~s}^{-1}$. Given that the operational conditions were the same, this decline in BPA removal can be explained by the non-selective nature of ${ }^{\bullet} \mathrm{OH}$ radical and other oxidants. Thus, the coexisting pollutants compete for the same amount of oxidants electrogenerated, and this leads to a decrease in the overall removal rate.

Interestingly, the Fenton-based processes were also affected by the presence of species that competed for the electrogenerated oxidants. In the case of the EF process, which attained complete BPA removal in the real matrix after 10 min of treatment, only $65.9 \%$ of BPA was degraded in the same matrix when $\mathrm{MeP}$ and PCA were present at the same initial concentration. Instead, 40 min of EF treatment were required to degrade BPA in the solution containing the interfering species. The competition for hydroxyl radical between the different pollutants decreased the pseudo first-order rate constant of BPA removal in real water from $5.11 \times 10^{-3} \mathrm{~s}^{-1}$ down to $1.72 \times 10^{-3} \mathrm{~s}^{-1}$ (almost a 3 -fold decrease). The PEF process exhibited identical pattern of behavior in which the kinetic constant of BPA removal declined from $5.93 \times 10^{-3} \mathrm{~s}^{-1}$ to $2.13 \times 10^{-3} \mathrm{~s}^{-1}$. Depending on the nature of the coexisting pollutants, the light employed in the process may be absorbed by the organic substances in solution, decreasing 
its transport. However, the main cause of the decline in kinetic constant seemed to be associated with the competitive consumption of electrogenerated oxidants.

The study of the mineralization of the solution investigated gave us the results discussed previously. The rate of mineralization obtained was in the following order: $\mathrm{PEF}>>\mathrm{EF}>\mathrm{EO}-$ $\mathrm{H}_{2} \mathrm{O}_{2}$, where the use of only direct photolysis was insufficient to achieve the incineration of the organic substances (commonly observed for photostable compounds).

The experiment using EO- $\mathrm{H}_{2} \mathrm{O}_{2}$ presented a steady TOC decay, leading to $40.8 \%$ of TOC removal after $300 \mathrm{~min}$ of treatment. This gradual mineralization is attributed to the presence of heterogeneous $\operatorname{BDD}\left({ }^{\bullet} \mathrm{OH}\right)$ and the control of organic substances by mass transport from/toward the anode surface. The test conducted under the EF process exhibited a noticeable total organic carbon removal of about $53.6 \%$ during the first 180 min, remaining practically constant thereafter. This quick initial mineralization may be linked to the oxidation of some intermediates by the homogeneous ${ }^{\bullet} \mathrm{OH}$ radicals and the weaker oxidants electrogenerated in the bulk, which can lead to the formation of recalcitrant compounds that are sluggishly destroyed by these same oxidants or by $\operatorname{BDD}\left({ }^{\bullet} \mathrm{OH}\right)$. These recalcitrant compounds have been reported to be mainly composed of carboxylic acids which form stable complexes with iron (III). The formation of these complexes leads to the trapping of the catalyst in the Fenton reaction process, slowing down the magnitude of the reaction. In addition, these stable organo-complexes have demonstrated to be more resistant to oxidation than non-complexed acids. These effects have been associated with the strong deceleration of TOC removal at longer electrolysis periods under the EF treatment process $[37,38]$. The use of the PEF treatment process enabled us to overcome this constraint through the application of UVC light which promoted the photodecarboxylation of the complexes, leading to almost complete TOC removal from the water matrix containing the mixture of 
endocrine disruptors at the end of the treatment time. To improve our understanding of the process involving the generation of intermediate compounds, the concentration of shortchain carboxylic acids - which are final by-products of the PEF process, was analyzed by HPLC. Fig. 4c shows the evolution of the concentration of acetic, formic, malic, and oxalic acids over time in the degradation process of real wastewater containing $0.14 \mathrm{mmol} \mathrm{L}^{-1} \mathrm{BPA}$, $0.14 \mathrm{mmol} \mathrm{L}^{-1} \mathrm{MetP}$, and $0.14 \mathrm{mmol} \mathrm{L}^{-1} \mathrm{PAC}$. There was a gradual maximum accumulation of the carboxylic acids tested and all of them were practically removed after $300 \mathrm{~min}$ of treatment. The acetic acid, which was probably obtained mainly from the cleavage of the benzene rings of the endocrine disruptors, presented a maximum accumulation of $17.70 \mathrm{mg}$ $\mathrm{L}^{-1}$ during the first $60 \mathrm{~min}$. Formic, malic, and oxalic acids persisted in the oxidation process of the carboxylic acids and presented maximum accumulations of 14.19, 3.96 and $22.32 \mathrm{mg}$ $\mathrm{L}^{-1}$ at $120 \mathrm{~min}, 60 \mathrm{~min}$, and 60-120 min, respectively. These acids were directly mineralized to $\mathrm{CO}_{2}$. The main conclusion that can be drawn here is that the EAOPs are capable of completely mineralizing the organic load of polluted effluents irrespective of the nature of the persistent organic pollutants contained in the water matrix. However, the degradation kinetics of a specific target pollutant (such as BPA) may experience a significant decline in water matrices containing many interfering pollutants compared to pure water or real matrices containing only one target pollutant. In this context, complete TOC removal may be a straightforward indicator of water quality for researchers or analysts when the EAOP treatment technique is applied in centralized treatment plants. 

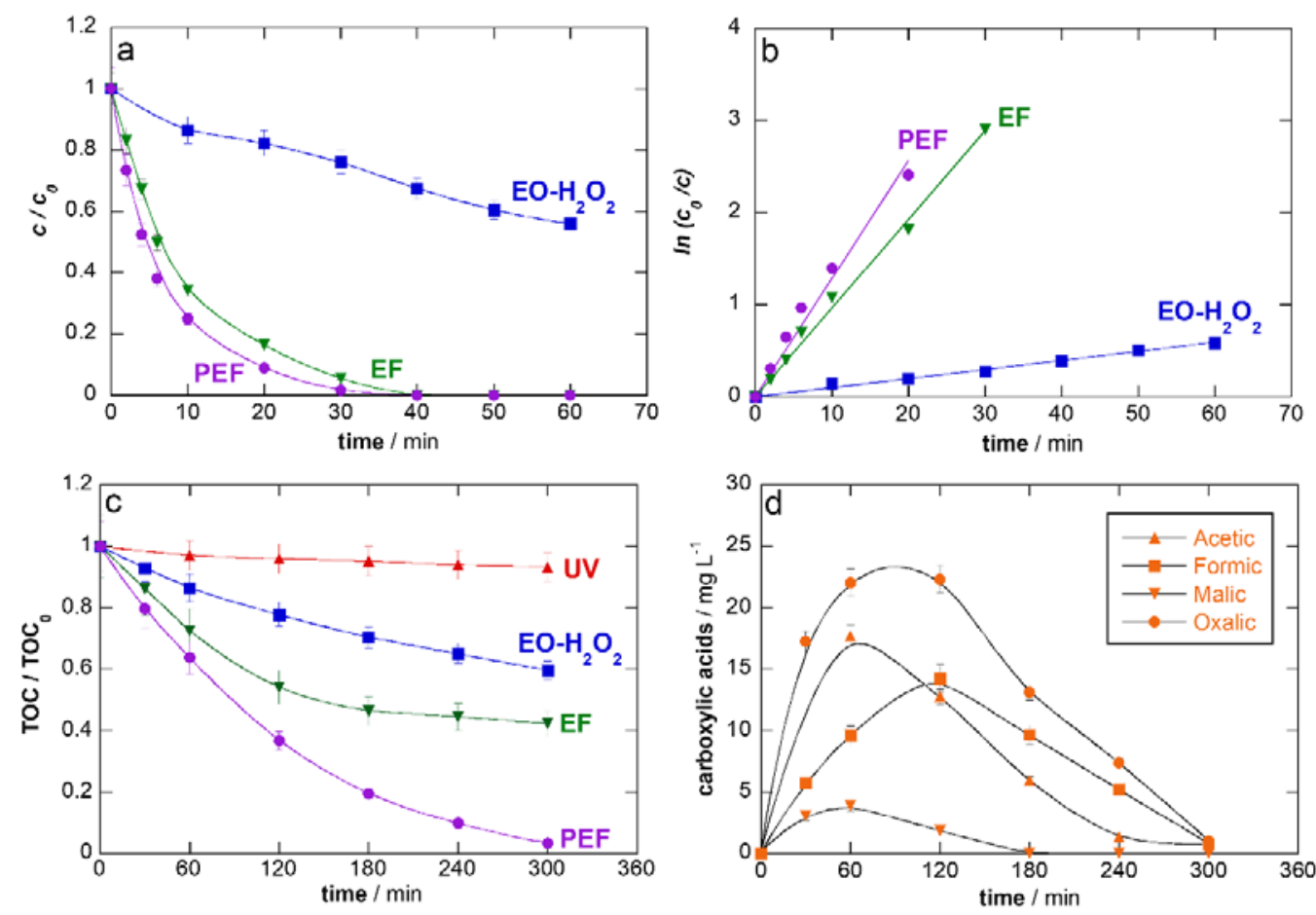

Fig. 3. a) Normalized BPA concentration decay in a mixture of different endocrine disruptors $\left(0.14 \mathrm{mmol} \mathrm{L}^{-1} \mathrm{BPA}, 0.14 \mathrm{mmol} \mathrm{L}^{-1}\right.$ methyl paraben, and $0.14 \mathrm{mmol} \mathrm{L}^{-1}$ paracetamol) over time using EO- $\mathrm{H}_{2} \mathrm{O}_{2}, \mathrm{EF}$ and PEF processes and b) respective pseudo-first order kinetics. c) Normalized TOC decay in a mixture of different endocrine disruptors over time using photolysis, EO- $\mathrm{H}_{2} \mathrm{O}_{2}, \mathrm{EF}$, and PEF processes. d) Evolution of the carboxylic acids concentration over time under the PEF process. Operating conditions: real wastewater, $\mathrm{pH}$ $3.0, j=33.3 \mathrm{~mA} \mathrm{~cm}{ }^{-2}, 0.5 \mathrm{mmol} \mathrm{L}^{-1} \mathrm{Fe}^{2+}$ used as catalyst for the Fenton reactions, and UVC lamp for the PEF.

\subsection{Optimization of operating conditions for the electrochemical oxidation process}

Although Fenton-based processes are regarded highly competitive, the techniques are found to be limited to a narrow acidic $\mathrm{pH}$ range of about 3.0. Indeed, this is a major limitation when it comes to the treatment of large volumes of matrices that require $\mathrm{pH}$ adjustment prior and after the treatment. In contrast, $\mathrm{EO}-\mathrm{H}_{2} \mathrm{O}_{2}$ can be potentially competitive under extensive 
range of operation conditions. The present study sought to investigate the influence of different variables on the degradation efficiency and competitiveness of $\mathrm{EO}-\mathrm{H}_{2} \mathrm{O}_{2}$. Fig. 4 illustrates the impact of different operating conditions, which include $\mathrm{pH}$, applied current density, and initial BPA concentration, on the performance of the $\mathrm{EO}-\mathrm{H}_{2} \mathrm{O}_{2}$ treatment process.

The $\mathrm{pH}$ is one of the major constraints in the search for competitive treatment techniques for implementation. Fig. 4a shows a steady decrease in the contaminant degradation with the increase in $\mathrm{pH}$ values based on the application of the $\mathrm{EO}-\mathrm{H}_{2} \mathrm{O}_{2}$ treatment process. A similar pattern of behavior was also observed for TOC removal. BPA removal of $71 \%$ was obtained for the contaminant concentration at $\mathrm{pH} 10$ after 60 min of treatment $\left(k_{1}=3.17 \times 10^{-4} \mathrm{~s}^{-1}, \mathrm{R}^{2}=\right.$ 0.995). Furthermore, an increase of 1.8 -fold $\left(k_{1}=5.84 \times 10^{-4} \mathrm{~s}^{-1}, \mathrm{R}^{2}=0.993\right)$ and 5.7 -fold $\left(k_{1}\right.$ $\left.1.82 \times 10^{-3} \mathrm{~s}^{-1}, \mathrm{R}^{2}=0.995\right)$ in $k_{1}$ was observed for $\mathrm{pH} 7.0$ and $\mathrm{pH} 3.0$, respectively. Under the acidic medium, the use of the EO- $\mathrm{H}_{2} \mathrm{O}_{2}$ treatment process led to a sharp removal of BPA $(89.3 \%)$ in the first 20 min of treatment, and the compound disappeared completely after 40 min. In both water matrices, the $\mathrm{EO}-\mathrm{H}_{2} \mathrm{O}_{2}$ process was found to be mostly influenced by the $\operatorname{BDD}\left({ }^{\bullet} \mathrm{OH}\right)$ radicals and the electrogeneration of active chlorine species. As discussed previously, the presence of chloride enhances the degradation kinetics due to the action of homogeneous active chlorine species in the bulk. However, the oxidation capabilities of active chlorine species are intimately related to the $\mathrm{pH}$, which also defines their speciation. Indeed, the oxidation of the pollutant in the presence of chlorine species is more extended in acidic than in alkaline media due to the higher standard potential of $\mathrm{HClO}\left(\mathrm{E}^{0}=1.49 \mathrm{vs}\right.$. SHE) compared to $\mathrm{ClO}^{-}\left(\mathrm{E}^{0}=0.89\right.$ vs. SHE) [29]. The electrogeneration of hydroxyl radical and its oxidation capabilities are also affected by the $\mathrm{pH}$ [39] though not as strongly as the effect observed in chlorine species [40]. This observation can help explain the pattern of 
behavior similarly observed for the TOC removal in the inset of Fig. 4a. The energy required to remove one unit of BPA $(\mathrm{EE} / \mathrm{O})$ was determined for each $\mathrm{pH}$ in the simulated medium based on Eq. 7. The experiment at $\mathrm{pH} 3.0$ yielded $\mathrm{EE} / \mathrm{O}$ value of $2.80 \mathrm{kWh} \mathrm{m}^{-3}$ order $^{-1}$; this value is 3.3 -fold and 6.3 -fold inferior to the values obtained at $\mathrm{pH} 7.0$ and 10 , respectively (Fig. 4b). The results of these experiments showed that the best initial $\mathrm{pH}$ to work with is the acidic $\mathrm{pH}(\sim 3.0)$, although the major strength of $\mathrm{EO}-\mathrm{H}_{2} \mathrm{O}_{2}$ is its possible application under the natural $\mathrm{pH}$ of water effluents (6.0-8.0).

The applied current density $j$ is among the key parameters that exert influence over the electrokinetics of EAOPs. The current density defines the quantity of electrons that flow in the system and, consequently, the amount of oxidizing mediator species that can be electrogenerated [41]. The influence of current density was assessed in the range of 16.7 to $66.7 \mathrm{~mA} \mathrm{~cm}^{-2}$. Fig. $4 \mathrm{c}$ shows that an increase in the applied $j$ led to a decrease in the normalized concentration decay of BPA. These results help infer that the higher amounts of - OH radicals, peroxydisulfate, and active chlorine electrogenerated in the process contributed toward the increase in the degradation kinetics. In fact, the $k_{1}$ was doubled when the applied $j$ was increased from $16.7 \mathrm{~mA} \mathrm{~cm}^{-2}$ to $33.3 \mathrm{~mA} \mathrm{~cm}$. Nevertheless, almost no variation $(\sim 1.3 \mathrm{x})$ was observed when the applied current density was increased further to $66.7 \mathrm{~mA} \mathrm{~cm}^{-}$ ${ }^{2}$ (Fig. 4d). These results allow one to infer that there is a transition from degradation kinetics limited by current to a degradation kinetics limited by the transport of pollutants toward the electrode surface. The excess of electrons in the process is consumed by parasitic reactions that do not lead to organic degradation reactions, but that consume/scavenge ${ }^{\bullet} \mathrm{OH}$ radicals, as can be observed in reactions (22-26) and (31-33). Parasitic reactions affect the efficiency of the system and may unnecessarily increase the operational costs. The same pattern of behavior is also evident for the TOC removal, where the experiments conducted at current 
densities of $16.7,33.3$, and $66.7 \mathrm{~mA} \mathrm{~cm}^{-2}$ yielded TOC removal of $23.9 \%, 35.1 \%$, and $39.8 \%$, respectively (inset of Fig. 4c). Higher current densities resulted in higher degradation kinetics, which was, in turn, expected to lead to lower EE/O (Eq. 7); however, EE/O was found to be more affected by the increase of the cell potential (Pcell). Thus, based on the techno-economic aspects, one ought to find a middle-ground solution that minimizes retention time in the electrochemical cells while requiring an acceptable energy input. This parameter should be then defined for each specific case scenario.

$$
\begin{aligned}
& \mathrm{BDD}\left(\bullet^{\bullet} \mathrm{OH}\right) \rightarrow \mathrm{BDD}+1 / 2 \mathrm{O}_{2}+\mathrm{H}^{+}+\mathrm{e}^{-} \\
& \mathrm{H}_{2} \mathrm{O}_{2}+\bullet \mathrm{OH}^{\circ} \rightarrow \mathrm{HO}_{2} \bullet+\mathrm{H}_{2} \mathrm{O} \\
& 2^{\bullet} \mathrm{OH} \rightarrow \mathrm{H}_{2} \mathrm{O}_{2}
\end{aligned}
$$

An analysis of the impact of the initial concentration of BPA $\left(0.07-0.28 \mathrm{mmol} \mathrm{L}^{-1}\right)$ provides valuable information regarding the range of concentration that can be efficiently treated within reasonable periods of time, as illustrated in Fig. 4e. As can be observed, a decrease in the initial concentration of the pollutant led to an increase in the degradation kinetics from $8.01 \times 10^{-4} \mathrm{~s}^{-1}\left(\mathrm{R}^{2}=0.982\right)$ at $0.28 \mathrm{mmol} \mathrm{L}^{-1}$ to $1.53 \times 10^{-3} \mathrm{~s}^{-1}\left(\mathrm{R}^{2}=0.995\right)$ for 0.14 mmol L-1 BPA. A further decrease of the concentration to $0.07 \mathrm{mmol} \mathrm{L}^{-1} \mathrm{BPA}$ also led to an increase of up to $2.78 \times 10^{-3} \mathrm{~s}^{-1}\left(\mathrm{R}^{2}=0.996\right)$ in $k_{1}$ (see Fig. $4 \mathrm{f}$ ). Conducting experiments with higher concentrations of contaminants leads to the generation and accumulation of a larger number of intermediates and by-products, which tend to compete for the same amount of - $\mathrm{OH}$ radicals with the initial compounds. This ultimately leads to a decline in the pollutant degradation and an increase in EE/O (Fig. 5f). In the case of total organic carbon (TOC), the removal efficiency is found to be superior for the experiment with higher initial BPA concentration than with lower initial BPA concentration (inset Fig. 5e). It is worth noting that 
mineralization depends on the effective transport of BPA to the electrode surface, which improves in the presence of larger organic load. Indeed, when there is a higher probability of provoking the formation of oxidants for organic degradation reactions, this tends to diminish the extent/magnitude of parasitic reactions. However, it has become clear that electrochemical processes can be applied in a wide range of concentrations, and these processes can be highly effective for the removal of trace pollutants when they are applied in combination with one another in wastewater treatment plants. Similar behavior was observed in real water matrices (see Fig. S1). 

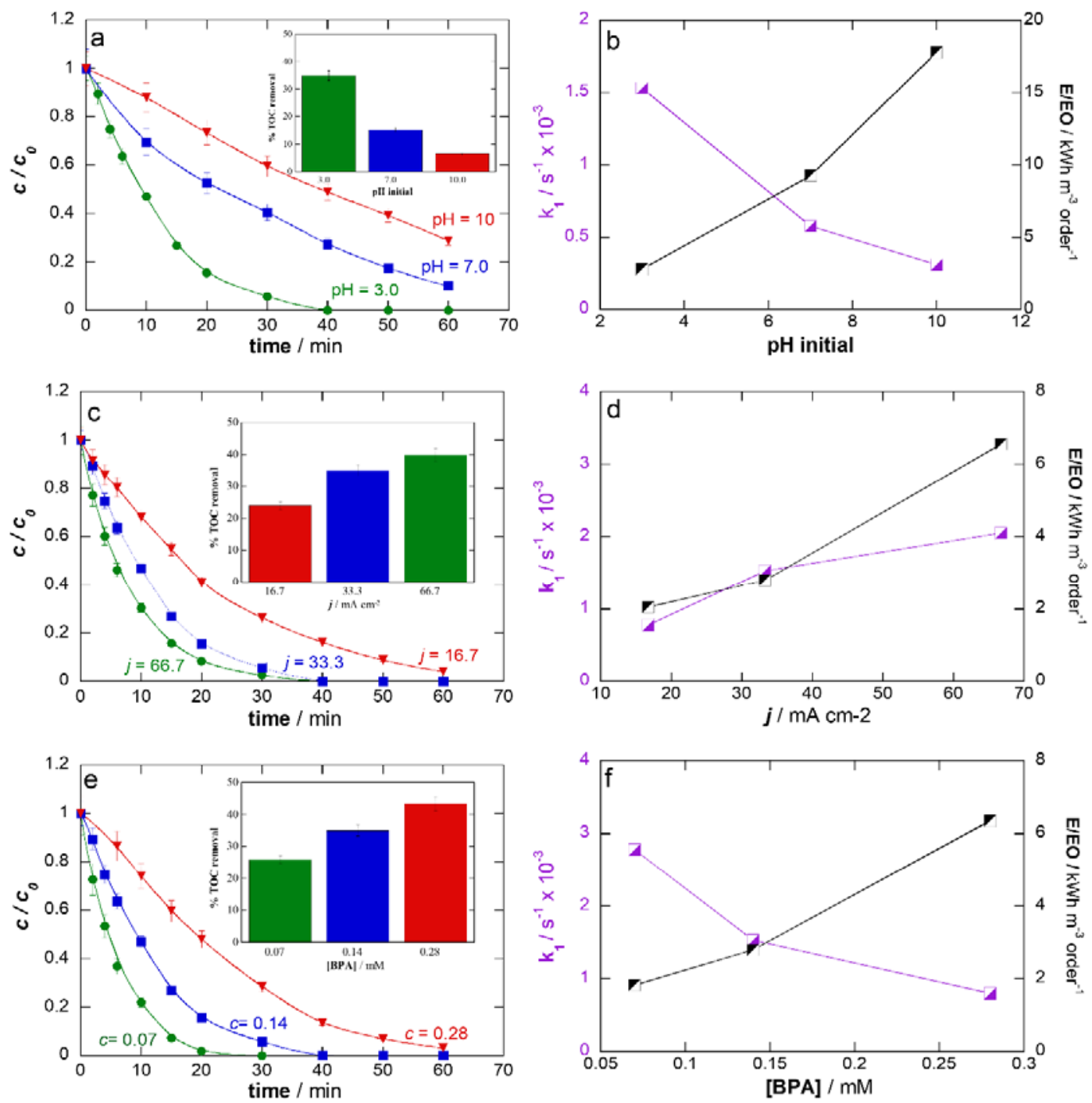

Fig. 4. Effect of a) initial $\mathrm{pH}$, c) current density, and e) initial pollutant concentration on the decay of BPA over time. Insets: Corresponding TOC removal of the parameters after 60 min of treatment. Kinetic analysis based on a pseudo-first order degradation reaction ( $\square$ ) versus electrical energy per order $(\boldsymbol{\square})$ for b) initial $\mathrm{pH}, \mathrm{d}$ ) current density, and f) initial pollutant concentration. 


\subsection{Time-course analysis of coexisting inorganic ions during the treatment of real wastewater}

Apart from the degradation performance, the time-course analysis of the ions in the solution under treatment is also a matter of great interest to this study. The inorganic ions were monitored during the treatment of $[\mathrm{BPA}]=0.14 \mathrm{mmol} \mathrm{L}-1$ at $\mathrm{pH} 3.0$ under the $\mathrm{EO}-\mathrm{H}_{2} \mathrm{O}_{2}$ treatment process at current density of $33.3 \mathrm{~mA} \mathrm{~cm}^{-2}$. Looking at Fig. 5, one will observe that $71 \%$ of the initial chloride species were converted into active chlorine species. However, further oxidation of the inorganic chlorine species led to the formation of $1.23 \mathrm{mg} \mathrm{L}^{-1} \mathrm{ClO}_{2}^{-}$ , $1.82 \mathrm{mg} \mathrm{L}^{-1} \mathrm{ClO}_{3}^{-}$, and $0.98 \mathrm{mg} \mathrm{L}^{-1} \mathrm{ClO}_{4}^{-}$. Chlorate and perchlorate are undesired species that may pose serious health risks to living organisms [42-44]. Under the framework of the World Health Organization (WHO), the maximum concentration level (MCL) of chlorate and perchlorate allowed in drinking water is $70 \mu \mathrm{g} \mathrm{\textrm {L } ^ { - 1 }}$ [45]. The US Environmental Protection Agency (US-EPA) has established an even more stringent MCL of $15 \mu \mathrm{g} \mathrm{L}^{-1}$ for chlorate and perchlorate in drinking water. Thus, the results obtained in the present study suggest that the treated water will not be suitable for drinking purposes without conducting additional treatment aimed at further reducing $\mathrm{ClO}_{3}{ }^{-}$and $\mathrm{ClO}_{4}{ }^{-}$. However, one will note that the concentration level of these undesired species observed in the treated water may be in full compliance with the specified maximum effluent limit of up to $10 \mathrm{mg} \mathrm{L}^{-1}$ of $\mathrm{ClO}_{4}^{-}$ allowed under the wastewater discharge permit in different wastewater treatment facilities [46].

$\mathrm{N}$-species are also susceptible to chemical and electrochemical transformations. Chromatographic analyses show that the initial ammonia $\left(\mathrm{NH}_{4}^{+}\right)$concentration of $5.81 \mathrm{mg}$ $\mathrm{L}^{-1}\left(4.5 \mathrm{mg} \mathrm{L}^{-1}\right.$ as $\left.\mathrm{N}\right)$ was completely removed at the end of the treatment. The complete 
disappearance of $\mathrm{NH}_{4}{ }^{+}$from the solution can be explained by its chemical reaction with the active chlorine species electrogenerated in the process. The chemical conversion of ammonia to innocuous nitrogen gas $\left(\mathrm{N}_{2}\right)$ occurs when a certain concentration of active chlorine species is obtained. This process occurs based on reaction (34), and it is referred to as the chlorine breaking point.

$$
3 \mathrm{HOCl}+2 \mathrm{NH}_{3} \rightarrow \mathrm{N}_{2}+3 \mathrm{H}_{2} \mathrm{O}+3 \mathrm{HCl}
$$

Under the EO- $\mathrm{H}_{2} \mathrm{O}_{2}$ treatment process, the initial nitrate $\left(\mathrm{NO}_{3}^{-}\right)$concentration was found to decrease from $8.67 \mathrm{mg} \mathrm{L}^{-1}$ to $1.08 \mathrm{mg} \mathrm{L}^{-1}\left(0.24 \mathrm{mg} \mathrm{L}^{-1}\right.$ as $\left.\mathrm{N}\right)$ after $60 \mathrm{~min}$ of electrolysis. This behavior can be attributed to the gradual cathodic reduction of nitrate via direct charge transfer process, which is not highly favored in carbonaceous electrodes [47]. Nitrate reduction can yield nitrite $\left(\mathrm{NO}_{2}{ }^{-}\right)$and $\mathrm{NH}_{4}{ }^{+}$, based on reactions (35) and (36), respectively. Furthermore, $\mathrm{NH}_{4}{ }^{+}$evolves into $\mathrm{N}_{2}$ based on reaction (37), as described previously; thus, this ion is not accumulated in the solution.

$$
\begin{aligned}
& \mathrm{NO}_{3}{ }^{-}+2 \mathrm{H}^{+}+2 \mathrm{e}^{-} \rightarrow \mathrm{NO}_{2}{ }^{-}+\mathrm{H}_{2} \mathrm{O} \\
& \mathrm{NO}_{3}{ }^{-}+10 \mathrm{H}^{+}+8 \mathrm{e}^{-} \rightarrow \mathrm{NH}_{4}{ }^{+}+3 \mathrm{H}_{2} \mathrm{O} \\
& 2 \mathrm{NH}_{4}{ }^{+}+8 \mathrm{H}^{+}+10 \mathrm{e}^{-} \rightarrow \mathrm{N}_{2}
\end{aligned}
$$

The concentration of $\mathrm{NO}_{2}{ }^{-}$changed gradually from $0.98 \mathrm{mg} \mathrm{L}^{-1}\left(0.30 \mathrm{mg} \mathrm{L}^{-1}\right.$ as $\left.\mathrm{N}\right)$ to 0.93 $\mathrm{mg} \mathrm{L}^{-1}\left(0.28 \mathrm{mg} \mathrm{L}^{-1}\right.$ as $\left.\mathrm{N}\right)$, and $\mathrm{NO}_{2}{ }^{-}$was further reduced to $\mathrm{NH}_{4}{ }^{+}$, but the sustained yield of $\mathrm{NO}_{2}{ }^{-}$as stable by-product of $\mathrm{NO}_{3}{ }^{-}$electrochemical reduction maintained the level of $\mathrm{NO}_{2}{ }^{-}$ during the electrolysis time under analysis. It is worth pointing out that the remaining concentrations of $\mathrm{NO}_{2}{ }^{-}$and $\mathrm{NO}_{3}{ }^{-}$were found to be below the MCLs for drinking water, which have been established to be $1.0 \mathrm{mg} \mathrm{L}^{-1}$ and $10.0 \mathrm{mg} \mathrm{L}^{-1}$ for $\mathrm{NO}_{2}^{-}$and $\mathrm{NO}_{3}^{-}$, respectively. 
These results show that there are some key water quality parameters that must be accounted for when it comes to assessing the efficiency of electrochemical treatments of organic pollutants. One will be able to thoroughly evaluate the full picture of the competitiveness of the treatment process once these quality parameters are accounted for. Although the Nspecies have met the quality criteria for drinking water, further treatment needs to be conducted in order to decrease the concentration of chlorine oxyanions.

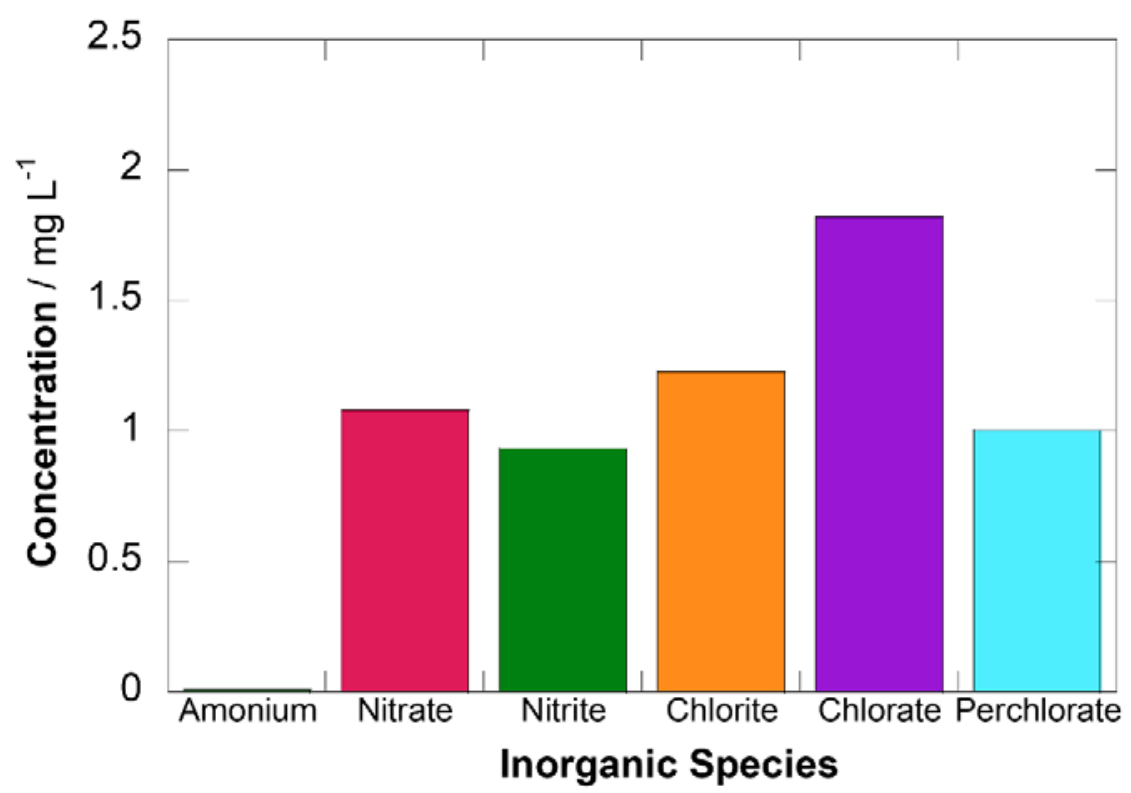

Fig. 5. Nitrogen and chloride-based species identified at the end of $60 \mathrm{~min}$ of treatment. Operating conditions - pollutant concentration: $0.14 \mathrm{mmol} \mathrm{L}^{-1} \mathrm{BPA}$; treatment process: EO$\mathrm{H}_{2} \mathrm{O}_{2}$; pH 3.0; current density (j) of $33.3 \mathrm{~mA} \mathrm{~cm}^{-2}$; and temperature of $25{ }^{\circ} \mathrm{C}$, using stirred undivided cell with BDD anode and carbon-PTFE cathode in real urban wastewater.

\section{Conclusions}

Having a comprehensive understanding of the effect of the complexity of different water matrices on the removal of endocrine disruptors is key to identifying specific areas for the 
application of electrochemical techniques based on $\mathrm{H}_{2} \mathrm{O}_{2}$ electrogeneration. The results of the present study show that $\mathrm{H}_{2} \mathrm{O}_{2}$ oxidant can be generated and accumulated irrespective of the medium employed in the treatment of both simple and complex matrices. The application of three different EAOPs for the treatment of different media containing BPA showed that the process involving the contaminant removal occurred in different ways under the techniques investigated and with different levels of efficiency. The Fenton reactions and the presence of UVC light promoted higher degradation rates (about 4.0-25 times higher than the EO- $\mathrm{H}_{2} \mathrm{O}_{2}$ process) due to the greater amount of homogeneous ${ }^{\bullet} \mathrm{OH}$ radicals generated in the system. The constituents of the water matrix, such as sulfate and chloride, and their concentration were found to play a key role in the generation of additional oxidants, such as peroxydisulfate and active chlorine species, which are regarded essential for the removal of endocrine disruptors. The undesired organic compounds present in the real wastewater investigated were found to affect the performance of the systems because they competed naturally with the target pollutant for the oxidants electrogenerated in the treatment process. Inorganic species, such as potassium, nitrate, and ammonia, showed no significant interference in the degradation of the contaminant. The coexistence of persistent organic pollutants (POPs) with the target pollutant (BPA) in the real wastewater investigated in this study increased the interference of these POPs in the degradation of BPA. Using the EO$\mathrm{H}_{2} \mathrm{O}_{2}$ treatment process and under the application of the same operating conditions adopted in the other treatment processes, the kinetic rate of BPA decreased from $3.91 \times 10^{-4} \mathrm{~s}^{-1}$ to $1.64 \times 10^{-4} \mathrm{~s}^{-1}$ due to the higher competition for the same amount of oxidants from the intermediate species and new by-products generated in the process. Regarding the analysis of TOC removal, the formation of a plateau was clearly observed during the EF process; this was probably due to the generation of sub-products such as iron complexes which are 
difficult to remove. This problem was overcome by the application of UVC light in the PEF process. Based on the time-course analysis of carboxylic acids, the results obtained show that the application of the PEF treatment mechanism can lead to a complete removal of the target compound from the system regardless of the nature of the competing persistent organic pollutants present in the wastewater matrix. Although the Fenton-based processes are highly competitive techniques, their acidic $\mathrm{pH}$ range requirement of approximately 3.0 hinders their broader applicability and implementation; this paves the way toward the use of the EO- $\mathrm{H}_{2} \mathrm{O}_{2}$ process since it provides one with the possibility of conducting the treatment under a wide range of $\mathrm{pH}$. The optimal operating conditions obtained under the application of the EO$\mathrm{H}_{2} \mathrm{O}_{2}$ process for the treatment of synthetic wastewater effluent were as follows: current density $=33.3 \mathrm{~mA} \mathrm{~cm}{ }^{-2} ; \mathrm{pH}=3$; and bisphenol A concentration $=0.14 \mathrm{mmol} \mathrm{L}^{-1}$; these optimal conditions yielded EE/O of $2.80 \mathrm{kWh} \mathrm{m}^{-3}$ order $^{-1}$. However, competitive levels of BPA degradation were obtained at $\mathrm{pH} 7.0$ and 10.0. The evolution of inorganic species was monitored during the treatment of real wastewater under the optimized conditions mentioned above; the results obtained showed that the initial chloride species were converted to active chlorine species, and further oxidation of these species led to the formation of $1.23 \mathrm{mg} \mathrm{L}^{-1}$ $\mathrm{ClO}_{2}{ }^{-}, 1.82 \mathrm{mg} \mathrm{L}^{-1} \mathrm{ClO}_{3}{ }^{-}$, and $0.98 \mathrm{mg} \mathrm{L}^{-1} \mathrm{ClO}_{4}^{-}$. The last two species are known to pose serious risks to human health and their concentration level observed in the treated effluent was far higher than the strictly low concentration levels established by the World Health Organization $\left(70 \mu \mathrm{g} \mathrm{L}^{-1}\right)$ and the United States Environmental Protection Agency $(15 \mu \mathrm{g} \mathrm{L}$ $\left.{ }^{1}\right)$. Indeed, the stringent legally established low concentration levels of these pollutants in water for human consumption make the use of the water treated here unsuitable for drinking purposes without further treatment to degrade or minimize its oxyanions content. It is worth noting, however, that the results obtained under the treatment process employed here show 
that the effluents treated meet the requirements to be discharged in wastewater facilities since the concentration levels of the pollutants are far below the limit of $10 \mathrm{mg} \mathrm{L}^{-1} \mathrm{ClO}_{4}^{-}$. Ammonia $\left(\mathrm{NH}_{4}{ }^{+}\right)$was not detected at the end of the treatment process. This outcome was attributed to the reaction of ammonia with the chlorinated species generated in the system and its conversion to innocuous nitrogen gas $\left(\mathrm{N}_{2}\right)$. With regard to $\mathrm{NO}_{3}^{-}$, its concentration recorded a decrease of approximately $87.5 \%$ at the end of the treatment. In fact, the reduction kinetics of the $\mathrm{NO}_{3}{ }^{-}$species is found to be widely affected by the type of electrodes material used. In addition, $\mathrm{NO}_{3}{ }^{-}$can further yield $\mathrm{NO}_{2}{ }^{-}$and $\mathrm{NH}_{4}{ }^{+}$. Nitrite concentration was found to be stable during the treatment process with almost no variation observed at the end of the treatment. Both $\mathrm{NO}_{3}^{-}$and $\mathrm{NO}_{2}^{-}$concentration levels were found to be within the maximum contamination levels allowed in drinking water.

This work highlights the challenges that different water matrices pose when it comes to the electrochemical treatment of organic pollutants aiming at obtaining potable water that is free from harmful pollutants or where the concentration levels of the compounds present in the water matrix are within the legal discharge limits allowed. Further studies need to be performed to improve the effectiveness of the EAOPs and to enhance their technology readiness level (TRL) to increase the competitiveness of these treatment processes. 


\section{Acknowledgements}

This work was funded by the Brazilian National Council for Scientific and Technological Development - CNPq (grant 465571/2014-0, 302874/2017-8 and 427452/2018-0), the São Paulo Research Foundation - FAPESP (grants \#2014/50945-4, \#2017/23464-3, \#2017/10118-0, \#2018/22210-0, \#2018/22211-7, \#2018/22022-0 and \#2019/20634-0,) and the Coordenação de Aperfeiçoamento de Pessoal de Nível Superior (CAPES - Finance Code 001). Dr. Ana S. Fajardo gratefully acknowledges the funding received from the European Union Horizon 2020 research and innovation program under the Marie Sklodowska-Curie grant agreement No. 843870. 


\section{References}

[1] M. Kummu, J.H.A. Guillaume, H. De Moel, S. Eisner, M. Flörke, M. Porkka, S. Siebert, T.I.E. Veldkamp, P.J. Ward, The world's road to water scarcity: Shortage and stress in the 20th century and pathways towards sustainability, Sci. Rep. 6 (2016) 116. doi:10.1038/srep38495.

[2] H.P.H. Arp, Emerging decontaminants, Environ. Sci. Technol. 46 (2012) 4259-4260. doi:10.1021/es301074u.

[3] J.B. Ellis, Pharmaceutical and personal care products (PPCPs) in urban receiving waters, Environ. Pollut. 144 (2006) 184-189. doi:10.1016/j.envpol.2005.12.018.

[4] S. Snyder, P. Westerhoff, E. Wert, Y. Yoon, Pharmaceuticals, Personal Care Products, and Endocrine Disruptors in Water: Implications for the Water Industry, Environ. Eng. Sci. 20 (2003) 449-469. doi:10.2175/193864705783865569.

[5] J.M. Brausch, G.M. Rand, A review of personal care products in the aquatic environment: Environmental concentrations and toxicity, Chemosphere. 82 (2011) 1518-1532. doi:10.1016/j.chemosphere.2010.11.018.

[6] M.J. Benotti, R.A. Trenholm, B.J. Vanderford, J.C. Holady, B.D. Stanford, S.A. Snyder, Pharmaceuticals and endocrine disrupting compounds in U.S. drinking water, Environ. Sci. Technol. 43 (2009) 597-603. doi:10.1021/es801845a.

[7] V. Mustieles, S.C. D’Cruz, S. Couderq, A. Rodríguez-Carrillo, J.B. Fini, T. Hofer, I.L. Steffensen, H. Dirven, R. Barouki, N. Olea, M.F. Fernández, A. David, Bisphenol A and its analogues: A comprehensive review to identify and prioritize effect biomarkers for human biomonitoring, Environ. Int. $144 \quad$ (2020) 105811. doi:10.1016/j.envint.2020.105811.

[8] R.B.P. Vidal, G.A. Ibañez, G.M. Escandar, A green method for the quantification of 
plastics-derived endocrine disruptors in beverages by chemometrics-assisted liquid chromatography with simultaneous diode array and fluorescent detection, Talanta. 159 (2016) 336-343. doi:10.1016/j.talanta.2016.06.049.

[9] A. Jhones dos Santos, I. Sirés, E. Brillas, Removal of bisphenol A from acidic sulfate medium and urban wastewater using persulfate activated with electroregenerated Fe2+, Chemosphere. 263 (2021) 1-11. doi:10.1016/j.chemosphere.2020.128271.

[10] W.L. Ma, X. Zhao, Z.F. Zhang, T.F. Xu, F.J. Zhu, Y.F. Li, Concentrations and fate of parabens and their metabolites in two typical wastewater treatment plants in northeastern China, Sci. Total Environ. $644 \quad$ (2018) 754-761. doi:10.1016/j.scitotenv.2018.06.358.

[11] G. V. Fortunato, M.S. Kronka, A.J. dos Santos, M. Ledendecker, M.R.V. Lanza, Low Pd loadings onto Printex L6: Synthesis, characterization and performance towards $\mathrm{H} 2 \mathrm{O} 2$ generation for electrochemical water treatment technologies, Chemosphere. 259 (2020) 127523. doi:10.1016/j.chemosphere.2020.127523.

[12] J.R. Steter, E. Brillas, I. Sirés, Solar photoelectro-Fenton treatment of a mixture of parabens spiked into secondary treated wastewater effluent at low input current, Appl. Catal. B Environ. 224 (2018) 410-418. doi:10.1016/j.apcatb.2017.10.060.

[13] R.C. Burgos-Castillo, I. Sirés, M. Sillanpää, E. Brillas, Application of electrochemical advanced oxidation to bisphenol A degradation in water. Effect of sulfate and chloride ions, Chemosphere. 194 (2018) 812-820. doi:10.1016/j.chemosphere.2017.12.014.

[14] C.A. Martínez-Huitle, M. Panizza, Electrochemical oxidation of organic pollutants for wastewater treatment, Curr. Opin. Electrochem. $11 \quad$ (2018) 62-71. doi:10.1016/j.coelec.2018.07.010.

[15] M. Panizza, G. Cerisola, Direct and mediated anodic oxidation of organic pollutants, 
Chem. Rev. 109 (2009) 6541-6569. doi:10.1021/cr9001319.

[16] J.F. Carneiro, F.L. Silva, A.S. Martins, R.M.P. Dias, G.M. Titato, Á.J. Santos-Neto, R. Bertazzoli, M.R.V. Lanza, Simultaneous degradation of hexazinone and diuron using ZrO2-nanostructured gas diffusion electrode, Chem. Eng. J. 351 (2018) 650659. doi:10.1016/j.cej.2018.06.122.

[17] E. Brillas, I. Sirés, M.A. Oturan, Electro-fenton process and related electrochemical technologies based on fenton's reaction chemistry, Chem. Rev. 109 (2009) 65706631. doi:10.1021/cr900136g.

[18] C. Trellu, Y. Péchaud, N. Oturan, E. Mousset, D. Huguenot, E.D. van Hullebusch, G. Esposito, M.A. Oturan, Comparative study on the removal of humic acids from drinking water by anodic oxidation and electro-Fenton processes: Mineralization efficiency and modelling, Appl. Catal. B Environ. 194 (2016) 32-41. doi:10.1016/j.apcatb.2016.04.039.

[19] A.J. dos Santos, P.L. Cabot, E. Brillas, I. Sirés, A comprehensive study on the electrochemical advanced oxidation of antihypertensive captopril in different cells and aqueous matrices, Appl. Catal. B Environ. $277 \quad$ (2020) 119240. doi:10.1016/j.apcatb.2020.119240.

[20] G. Ren, M. Zhou, P. Su, W. Yang, X. Lu, Y. Zhang, Simultaneous sulfadiazines degradation and disinfection from municipal secondary effluent by a flow-through electro-Fenton process with graphene-modified cathode, J. Hazard. Mater. 368 (2019) 830-839. doi:10.1016/j.jhazmat.2019.01.109.

[21] V.B. Lima, L.A. Goulart, R.S. Rocha, J.R. Steter, M.R.V. Lanza, Degradation of antibiotic ciprofloxacin by different AOP systems using electrochemically generated hydrogen peroxide, $\quad$ Chemosphere. $\quad 247 \quad$ (2020) 125807. 
doi:10.1016/j.chemosphere.2019.125807.

[22] E. Brillas, A review on the photoelectro-Fenton process as efficient electrochemical advanced oxidation for wastewater remediation. Treatment with UV light, sunlight, and coupling with conventional and other photo-assisted advanced technologies, Chemosphere. 250 (2020) 126198. doi:10.1016/j.chemosphere.2020.126198.

[23] A.J. dos Santos, C.A. Martínez-Huitle, I. Sirés, E. Brillas, Use of Pt and Boron-Doped Diamond Anodes in the Electrochemical Advanced Oxidation of Ponceau SS Diazo Dye in Acidic Sulfate Medium, ChemElectroChem. 5 (2018) 685-693. doi:10.1002/celc.201701238.

[24] S. Garcia-Segura, A.B. Nienhauser, A.S. Fajardo, R. Bansal, C.L. Coonrod, J.D. Fortner, M. Marcos-Hernández, T. Rogers, D. Villagran, M.S. Wong, P. Westerhoff, Disparities between experimental and environmental conditions: Research steps toward making electrochemical water treatment a reality, Curr. Opin. Electrochem. 22 (2020) 9-16. doi:10.1016/j.coelec.2020.03.001.

[25] C. Ridruejo, F. Centellas, P.L. Cabot, I. Sirés, E. Brillas, Electrochemical Fentonbased treatment of tetracaine in synthetic and urban wastewater using active and nonactive anodes, Water Res. 128 (2018) 71-81. doi:10.1016/j.watres.2017.10.048.

[26] R. Montenegro-Ayo, J.C. Morales-Gomero, H. Alarcon, S. Cotillas, P. Westerhoff, S. Garcia-Segura, Scaling up photoelectrocatalytic reactors: A TiO2 nanotube-coated disc compound reactor effectively degrades acetaminophen, Water (Switzerland). 11 (2019) 1-14. doi:10.3390/w11122522.

[27] J. Moreira, V. Bocalon Lima, L. Athie Goulart, M.R.V. Lanza, Electrosynthesis of hydrogen peroxide using modified gas diffusion electrodes (MGDE) for environmental applications: Quinones and azo compounds employed as redox 
modifiers, Appl. Catal. B Environ. $248 \quad$ (2019) 95-107. doi:10.1016/j.apcatb.2019.01.071.

[28] E. Brillas, C.A. Martínez-Huitle, Decontamination of wastewaters containing synthetic organic dyes by electrochemical methods. An updated review, Appl. Catal. B Environ. 166-167 (2015) 603-643. doi:10.1016/j.apcatb.2014.11.016.

[29] A.S. Fajardo, H.F. Seca, R.C. Martins, V.N. Corceiro, J.P. Vieira, M.E. QuintaFerreira, R.M. Quinta-Ferreira, Phenolic wastewaters depuration by electrochemical oxidation process using Ti/IrO2 anodes, Environ. Sci. Pollut. Res. 24 (2017) 75217533. doi:10.1007/s11356-017-8431-9.

[30] J.R. Steter, E. Brillas, I. Sirés, On the selection of the anode material for the electrochemical removal of methylparaben from different aqueous media, Electrochim. Acta. (2016). doi:10.1016/j.electacta.2016.11.125.

[31] A.M. Held, D.J. Halko, J.K. Hurst, Mechanisms of Chlorine Oxidation of Hydrogen Peroxide, J. Am. Chem. Soc. 100 (1978) 5732-5740. doi:10.1021/ja00486a025.

[32] A. Thiam, I. Sirés, J.A. Garrido, R.M. Rodríguez, E. Brillas, Effect of anions on electrochemical degradation of azo dye Carmoisine (Acid Red 14) using a BDD anode and air-diffusion cathode, Sep. Purif. Technol. $140 \quad$ (2015) 43-52. doi:10.1016/j.seppur.2014.11.012.

[33] A.S. Fajardo, A.J. dos Santos, E.C.T. de Araújo Costa, D.R. da Silva, C.A. MartínezHuitle, Effect of anodic materials on solar photoelectro-Fenton process using a diazo dye as a model contaminant, Chemosphere. 225 (2019) 880-889. doi:10.1016/j.chemosphere.2019.03.071.

[34] M.J. Martín de Vidales, M. Millán, C. Sáez, P. Cañizares, M.A. Rodrigo, Irradiatedassisted electrochemical processes for the removal of persistent pollutants from real 
wastewater, Sep. $\quad$ Purif. Technol. $175 \quad$ (2017) 428-434. doi:10.1016/j.seppur.2016.11.014.

[35] C. Barrera-Díaz, P. Cañizares, F.J. Fernández, R. Natividad, M.A. Rodrigo, Electrochemical Advanced Oxidation Processes: An Overview of the Current Applications to Actual Industrial Effluents, J. Mex. Chem. Soc. 58 (2014) 256-275.

[36] S. Garcia-Segura, M. Lanzarini-Lopes, K. Hristovski, P. Westerhoff, Electrocatalytic reduction of nitrate: Fundamentals to full-scale water treatment applications, Appl. Catal. B Environ. 236 (2018) 546-568. doi:10.1016/j.apcatb.2018.05.041.

[37] N. Oturan, S.O. Ganiyu, S. Raffy, M.A. Oturan, Sub-stoichiometric titanium oxide as a new anode material for electro-Fenton process: Application to electrocatalytic destruction of antibiotic amoxicillin, Appl. Catal. B Environ. 217 (2017) 214-223. doi:10.1016/j.apcatb.2017.05.062.

[38] I. Sirés, E. Brillas, M.A. Oturan, M.A. Rodrigo, M. Panizza, Electrochemical advanced oxidation processes: Today and tomorrow. A review, Environ. Sci. Pollut. Res. 21 (2014) 8336-8367. doi:10.1007/s11356-014-2783-1.

[39] J.P. Crow, C. Spruell, J. Chen, C. Gunn, H. Ischiropoulos, M. Tsai, C.D. Smith, R. Radi, W.H. Koppenol, J.S. Beckman, On the pH-dependent yield of hydroxyl radical products from peroxynitrite, Free Radic. Biol. Med. 16 (1994) 331-338. doi:10.1016/0891-5849(94)90034-5.

[40] A.J. dos Santos, S. Garcia-Segura, S. Dosta, I.G. Cano, C.A. Martínez-Huitle, E. Brillas, A ceramic electrode of $\mathrm{ZrO} 2-\mathrm{Y} 2 \mathrm{O} 3$ for the generation of oxidant species in anodic oxidation. Assessment of the treatment of Acid Blue 29 dye in sulfate and chloride media, Sep. Purif. Technol. $228 \quad$ (2019) 115747. doi:10.1016/j.seppur.2019.115747. 
[41] F.C. Moreira, R.A.R. Boaventura, E. Brillas, V.J.P. Vilar, Electrochemical advanced oxidation processes: A review on their application to synthetic and real wastewaters, Appl. Catal. B Environ. 202 (2017) 217-261. doi:10.1016/j.apcatb.2016.08.037.

[42] M.E.H. Bergmann, J. Rollin, T. Iourtchouk, The occurrence of perchlorate during drinking water electrolysis using BDD anodes, Electrochim. Acta. 54 (2009) 21022107. doi:10.1016/j.electacta.2008.09.040.

[43] M.E.H. Bergmann, J. Rollin, A.S. Koparal, Chlorate and perchlorate - new criterions for environmentally-friendly processes in Advanced Oxidation, Water Pract. Technol. 5 (2010). doi:10.2166/wpt.2010.031.

[44] H. Bergmann, T. Iourtchouk, W. Schmidt, G. Nüske, M. Fischer, Perchlorate formation in electrochemical water disinfection, Perchlorates Prod. Uses Heal. Eff. (2011) 112-141.

[45] Perchlorate in drinking-water, Background document for development of WHO Guidelines for Drinking-water Quality, WHO Press. World Heal. Organ. 20 Ave. Appia, $1211 \quad$ Geneva $\quad 27, \quad$ Switz. www.who.int/water_sanitation_health/dwq/chemicals/antimony.pdf.

[46] National Aeronautics and Space Administration (NASA), Perchlorate (ClO4) treatment technologies literature review - Operable unit 1 expanded treatability study, Natl. Aeronaut. Sp. Adm. JET Propuls. Lab. PASADENA, Calif. (2006). https://jplwater.nasa.gov/Docs/NAS710428.PDF.

[47] A.S. Fajardo, P. Westerhoff, C.M. Sanchez-Sanchez, S. Garcia-Segura, Earthabundant elements a sustainable solution for electrocatalytic reduction of nitrate, Appl. Catal. B Environ. 281 (2021) 119465. doi:10.1016/j.apcatb.2020.119465. 